\title{
IMPACT OF INDUSTRY ON GROUND WATER CONTAMINATION: A CASE STUDY IN KONYA CITY, TURKEY
}

\author{
NALBANTCILAR M.T..$^{1, *}$ \\ PINARKARA D. ${ }^{2}$
}

Received: $17 / 03 / 2015$

Accepted: $12 / 11 / 2015$

Available online: 13/11/2015

\author{
${ }^{1}$ Batman University, Geological Engineering Department \\ Batman, Turkey \\ ${ }^{2}$ Konya City Municipality, Konya, Turkey
}

\begin{abstract}
Having developed rapidly in recent years, Konya, one of Turkey's most significant industrial cities, has been hosting production activities in sectors such as glass, chemistry, mining, metal and machine in the factories $96 \%$ of which located in the third Organized Industrial Zone. In common environmental agenda, it was suggested that wastewater stemming from increased industrial diversity and some geological lithology can create environmental problems, including groundwater contamination. In this study, to characterize dry and rainy period, samples were collected from 11 wells so as to determine effects of wastes in the area on groundwater quality. The relation between industrialization and contamination was investigated in water samples, whose contents were examined for $\mathrm{NH}_{3}, \mathrm{NO}_{3}, \mathrm{SO}_{4}, \mathrm{~B}, \mathrm{Ca}, \mathrm{Cl}, \mathrm{Co}, \mathrm{Cr}, \mathrm{Cu}, \mathrm{Fe}$, $\mathrm{K}, \mathrm{Li}, \mathrm{Mg}, \mathrm{Mn}, \mathrm{Na}, \mathrm{Ni}, \mathrm{Sr}, \mathrm{V}$, and $\mathrm{Zn}$. Element distribution maps of locations where concentration rise occurred were determined in the vicinity. It was specified that $\mathrm{SO}_{4}, \mathrm{Ca}, \mathrm{Cl}, \mathrm{Na}, \mathrm{Cr}, \mathrm{Mg}, \mathrm{Mn}$, $\mathrm{Ni}$ and $\mathrm{Zn}$ in samples exceeded the maximum contaminant levels according to WHO, EPA and EC standards. It was determined that water samples belonging to rainy period were contaminated more than that of dry period, which poses a threat to environment.
\end{abstract}

Keywords: contamination; environment; ground water; industry; Turkey

\section{Introduction}

The contamination problem in groundwater has started to be talked about in many studies due to increasing industrial development in the World (Sponza and Karaoglu, 2002; Gowd and Govil, 2008; Krlshna and Mohan, 2014). Contamination has a significant vital risk especially for people who use this water for drinking and usage. Negative results that are at a level to affect the health of people are faced due to its effect (Yildiz et al., 2008). Factory wastes concerned with industrial manufacturing may have potential that may cause contamination (Nalbantcilar and Pinarkara, 2011; Nas, 1998; Arundas, 2010; Shankar et al., 2008; Ullah et al., 2009; Azizullah et al., 2011). The fact that industrial zones cause water contamination in has been demonstrated in many samples. Moreover, numerous studies have reported water contamination originating from industrial zones (Sponza and Karaoglu, 2002; Gowd and Govil, 2008; Krishna and Mohan, 2014; Shankar et al., 2008; Ullah et al., 2009; Azizullah et al., 2011; Krishna et al., 2009; Dasaram et al., 2011; Afzal et al., 2014).

This study was performed in the third Organized Industrial Zone (OIZ), where 168 industrial plants are located approximately $20 \mathrm{~km}$ northwest of the city centre of Konya, which is situated in the central part of Turkey (Figure 1). Since a variety of industrial productions such as metallurgy, mining, food, and electronics, among many others have been conducted in the OIZ, it has been asked whether all kinds of 
materials from products to the waste emerging in their productions processes contaminate the groundwater in the vicinity. This study thus aimed to determine the relationship between industrial production in the OIZ and groundwater quality. This study will provide important contributions to the water supply policy of the region as it is the first research study of its kind for this aim.

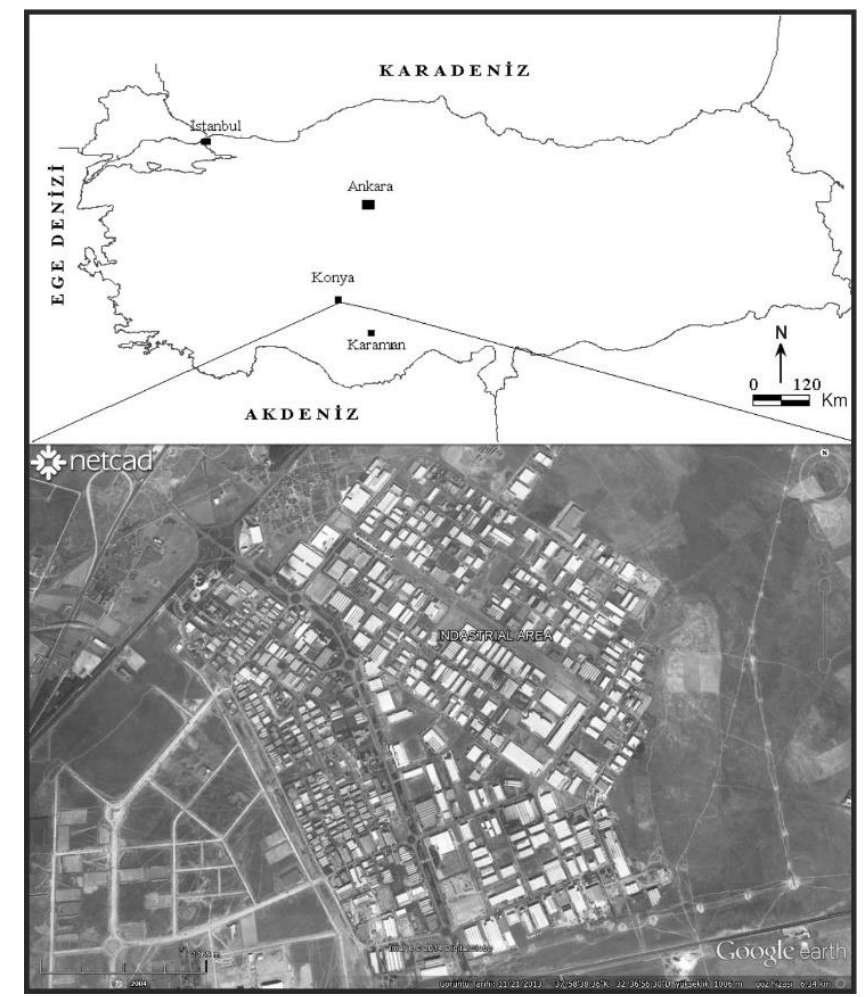

Figure 1. Location map of the study area

Geological studies of the investigation zone and the vicinity have been performed (Hakyemez et al., 1992; Eren, 2001), as have various studies on groundwater quality and contamination (Nalbantcilar and Pınarkara, 2011; Ozdemir and Aydin, 1998; Nalbantcilar, 2002; Nalbantcilar and Guzel, 2006; Pinarkara, 2011), environmental problems (Nalbantcilar and Ozdemir, 2009), risks of contaminating aquifers (Nalbantcilar, 2008; Nalbantcilar et al., 2009; Nalbantcilar, 2011), and the properties of industrial zoneoriginated waste have been conducted (Nas, 1998; Arundas, 2010). In the regions close to the study area, contamination likely to affect public health was found in the drinking water wells (Nalbantcilar, 2002; Nalbantcilar and Guzel, 2006).

The aim of this study is the establishment of physical and chemical indexes to monitor the contamination of groundwater in the OIZ. For this purpose, it is researched whether the OIZ, the source of industrial contamination determined from waste water analyzes and in which chemistry, metal and machinery factories are located, has an effect on groundwater or not.

\subsection{Hydrogeology}

As Figure 2 shows, the geology of the $\mathrm{OIZ}$ and its environment comprises Late Pleistocene formation (Konya formation) consisting of a few attached siltstones, sandstones, and conglomerates, as well as Pleistocene to Holocene formation (Aslimyayla formation) with the properties of salty swamps and consisting of salt, gypsum, and intermediate-level mudstones (Hakyemez et al., 1992; Eren, 2001).

While conglomerates are badly sorted and semi-spherical in Konya formation and though their coarsegrained sandstones have high permeability, their siltstones exhibit impermeable properties. Therefore, this formation is classified as less permeable. The total porosity of Konya formation ranges from $26 \%$ to $33 \%$; however, the addition of siltstone lowers their porosity (Pinarkara, 2011). The mudstones in 
Aslimyayla formation and parallel layered gypsums are impermeable. The total porosity of Aslimyayla formation is 34\% (Pinarkara, 2011), though gypsum-bearing levels in the formation lower their porosity.

It has been reported that Aslimyayla formation is weak in terms of surface recharge properties, yet that Konya formation are very high in this regard (Nalbantcilar, 2002). Furthermore, their storage coefficient shows unconfined aquifer property from 0.07-0.11\% (Nalbantcilar, 2002; Nalbantcilar and Guzel, 2006). The depth of the water level in the area ranges from 5-12 $\mathrm{m}$.

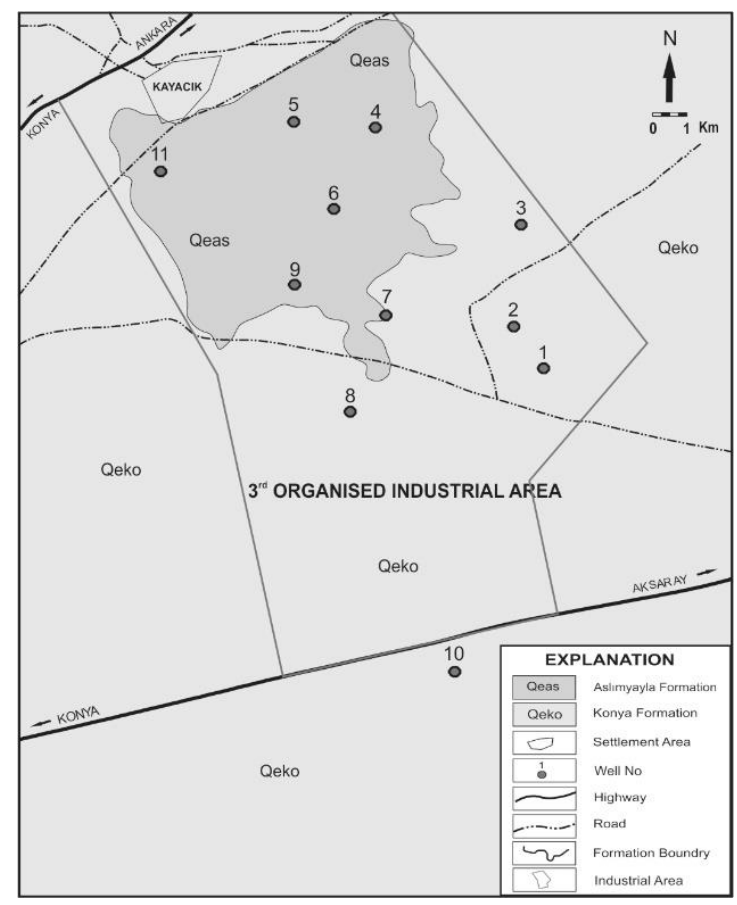

Figure 2. Geological map of the study area (modified from Hakyemez et al., 1992) and the groundwater sampling wells

\subsection{Properties of the OIZ}

Konya's third OIZ is located in an area of about 900 ha and consists of 168 industrial plants, most of which perform production-related processes (Table 1). The work performed in these plants involves industrial sectors such as wood, glass, metal, chemistry, and mining. In fact, sectors associated with glass, chemistry, mining, metal, and machine production comprise $96 \%$ of the OIZ's total production.

Table 1. Types of sectors in the third OIZ, number of firms and their rate (Pinarkara, 2011)

\begin{tabular}{|c|c|c|}
\hline \multirow{2}{*}{$\begin{array}{c}\text { Sectoral Types } \\
\text { Wooden products and furniture industry sector }\end{array}$} & \multicolumn{2}{|c|}{ Firms Number and Ratio (\%) } \\
\hline & 2 & 1 \\
\hline Glass industry sector & 60 & 36 \\
\hline Food industry sector & 4 & 2 \\
\hline Chemistry industry sector & 17 & 10 \\
\hline Mining industry sector & 10 & 6 \\
\hline Metal industry sector & 22 & 13 \\
\hline Cellulose, paper, carton industry sector & 2 & 1 \\
\hline $\begin{array}{l}\text { Mass machine production, electrical machines and } \\
\text { equipment, spare part industry sector }\end{array}$ & 48 & 29 \\
\hline Textile industry sector & 3 & 2 \\
\hline Total & 168 & 100 \\
\hline
\end{tabular}

Each day, approximately $4,000 \mathrm{~m}^{3}$ of process and domestic wastewater containing liquid waste and the 
OIZ waste is transmitted to a wastewater treatment plant. Water treated there is collected in a treated water treatment pool and used to irrigate recreational fields and/or as process water in the OIZ (Arundas, 2010). Domestic and industrial solid waste from factory production also emerges, so do raw materials and temporary waste disposals fields of factories in inventory fields. These wastes are generally influenced by climatic conditions, and contamination due to rainfall can mix with groundwater directly.

While domestic wastewater emerges due to wood processing and both furniture and glass production, process wastewater emerges in other sectors and can contain $\mathrm{Cd}, \mathrm{Cr}, \mathrm{Cu}, \mathrm{Fe}, \mathrm{N}, \mathrm{P}, \mathrm{Pb}$, and $\mathrm{Zn}$ (Table 2).

Table 2. Average waste water analysis values in the third OIZ (I, III, V, and VI numbered of sampling points) (Arundas, 2010)

\begin{tabular}{lccccc}
\hline \multirow{2}{*}{ Parameters } & \multicolumn{5}{c}{ Wastewater Analyses } \\
\cline { 2 - 6 } & $\mathbf{I}$ & III & V & VI & Mean \\
\hline $\mathrm{EC}\left(\mu \mathrm{mhos} \mathrm{cm}{ }^{-1}\right)$ & 18476 & 8224 & 13773 & 11095 & 12892 \\
\hline $\mathrm{Cd}(\mathrm{ppm})$ & 0.031 & 0.0236 & 0.0272 & 0.0268 & 0.027 \\
\hline $\mathrm{Cr}(\mathrm{ppm})$ & 0.0274 & 0.0234 & 0.0274 & 0.0432 & 0.030 \\
\hline $\mathrm{Cu}(\mathrm{ppm})$ & 0.481 & 0.61 & 1.638 & 1.16 & 0.97 \\
\hline $\mathrm{Fe}(\mathrm{ppm})$ & 1.69 & 2.63 & 7.35 & 9.19 & 5.21 \\
\hline $\mathrm{N}(\mathrm{ppm})$ & 9.0 & 10.7 & 12.6 & 21.2 & 13.38 \\
\hline Total P $(\mathrm{ppm})$ & 2.70 & 3.21 & 3.78 & 6.37 & 4.02 \\
\hline $\mathrm{Pb}(\mathrm{ppm})$ & 0.568 & 0.760 & 0.94 & 0.693 & 0.74 \\
\hline $\mathrm{Zn}(\mathrm{ppm})$ & 0.63 & 0.435 & 0.469 & 0.42 & 0.49 \\
\hline
\end{tabular}

\section{Materials and Methods}

To establish the properties of the groundwater in the investigation area, 11 wells distributed over the area were identified so that they together could represent the total area (Figure 2). From August 2010 until March 2011, groundwater sampling was performed in these wells to characterize dry and rainy seasons for hydrochemical analysis.

In Water and Sewerage System Administration of Konya City Municipality (KOSKI) Water Analysis Laboratory, cation and anion analyses of the water samples filled in $1 \mathrm{~L}$ double-capped sterilized plastic bottles were performed according to the rules specified in the standard methods of the American Public Health Association (APHA, 1992). Trace element analyses of water samples, to which acidification was applied to achieve a $\mathrm{pH}>2$, were performed in Selcuk-Iltek Analytical Laboratories in Konya via inductively coupled plasma mass spectrometry.

The regions where results obtained having regional distributions and concentration rises were put forth. Moreover, the analysed results were evaluated according to WHO, EPA and EC drinking water standards. As a result, it was aimed to find out the points posing threat to the public health.

\section{Hydrochemical properties of groundwater}

Table 3 shows the results of dry period analyses (August 2010). The electrical conductivity (EC) of groundwater in the area ranged from $1389 \mu$ mhos cm$~^{-1}$ (Sample 3) to $6900 \mu \mathrm{mhos} \mathrm{cm}^{-1}$ (Sample 10). The total dissolved solids (TDS) of groundwater in the area ranged from $885 \mathrm{ppm}$ (Sample 3) to $4395 \mathrm{ppm}$ (Sample 10). Sulphate $\left(\mathrm{SO}_{4}\right)$ concentrations ranged from $196.29 \mathrm{ppm}$ (Sample 9) to $435.36 \mathrm{ppm}$ (Sample 10). The amount of iron (Fe) ranged from $0.389 \mathrm{ppm}$ (Sample 1) to $1.80 \mathrm{ppm}$ (Sample 2), while lithium (Li) values ranged from $0.057 \mathrm{ppm}$ (Sample 3) to $0.247 \mathrm{ppm}$ (Sample 10). Magnesium (Mg) concentrations fell between 66.60 ppm (Sample 3) and 283.50 ppm (Sample 10), whereas nickel (Ni) fell between 0.003 ppm 
(Sample 1) and $0.01 \mathrm{ppm}$ (Sample 5). Strontium (Sr) concentration was defined at levels ranging from 2.40 ppm (Sample 3) to $12.20 \mathrm{ppm}$ (Sample 10). In two water samples, zinc ( $\mathrm{Zn}$ ) showed concentrations ranging from $0.01 \mathrm{ppm}$ (Sample 10) to $3.50 \mathrm{ppm}$ (Sample 9). Meanwhile, manganese (Mn) appeared mostly concentrated in only two samples of which (Sample 1) reached $0.079 \mathrm{ppm}$. Lastly, copper (Cu) appeared in two samples only: Sample $1(0.002 \mathrm{ppm})$ and Sample $10(0.006 \mathrm{ppm})$. Also, the distributions of the analyses obtained from water samples collected in the study area are given in Figure 3 - 5.

Table 3. The results of dry period analyses on the water samples (in ppm; except as noted)

\begin{tabular}{|c|c|c|c|c|c|c|c|c|c|c|c|}
\hline Sample No & 1 & 2 & 3 & 4 & 5 & 6 & 7 & 8 & 9 & 10 & 11 \\
\hline $\begin{array}{c}\text { Well } \\
\text { coordinate (X) }\end{array}$ & 467678 & 467414 & 467490 & 466411 & 465888 & 466157 & 466501 & 466252 & 465878 & 467055 & 464897 \\
\hline $\begin{array}{c}\text { Well } \\
\text { coordinate }(\mathrm{Y})\end{array}$ & 4203519 & 4203813 & 4204523 & 4205223 & 4205259 & 4204578 & 4203893 & 4203257 & 4204093 & 4201487 & 4204928 \\
\hline $\mathrm{pH}$ & 7.24 & 7.33 & 7.05 & 6.8 & 6.86 & 6.84 & 6.97 & 7.36 & 6.97 & 7.08 & 6.94 \\
\hline $\begin{array}{c}\text { EC } \\
\left(\mu \mathrm{mhos} \mathrm{cm}^{-1}\right)\end{array}$ & 1925 & 1593 & 1389 & 1776 & 1795 & 1574 & 1648 & 1587 & 1746 & 6900 & 2220 \\
\hline TDS & 1226 & 1015 & 885 & 1131 & 1143 & 1003 & 1050 & 1011 & 1112 & 4395 & 1414 \\
\hline T Alkalinity & 442 & 484 & 447 & 474 & 498 & 494 & 517 & 498 & 432 & 475 & 456 \\
\hline $\begin{array}{l}\text { T Hardness } \\
\text { (Fr) }\end{array}$ & 73 & 82 & 71 & 86 & 90 & 80 & 82 & 81 & 87 & 168 & 90 \\
\hline $\begin{array}{l}\text { Turbidity } \\
\text { (NTU) }\end{array}$ & 4 & 6.1 & 0.4 & 3.8 & 0.4 & 0.4 & 0.5 & 0.4 & 0.4 & 30.7 & 0.4 \\
\hline $\mathrm{NH}_{3}$ & 0.066 & 0.02 & 0.02 & 0.02 & 0.02 & 0.02 & 0.02 & 0.02 & 0.02 & 1.1 & 0.02 \\
\hline $\mathrm{NO}_{3}$ & 1.8 & 6.5 & 14.3 & 12.1 & 9.6 & 7.4 & 8.9 & 9.4 & 12.1 & 10.8 & 6.2 \\
\hline $\mathrm{SO}_{4}$ & 217.68 & 262.51 & 234.66 & 280.64 & 282.85 & 263.21 & 270.37 & 262.3 & 196.29 & 435.36 & 302.66 \\
\hline B & 0.287 & 0.208 & 0.234 & 0.186 & 0.268 & 0.213 & 0.198 & 0.20 & 0.235 & 0.256 & 0.175 \\
\hline $\mathrm{Ca}$ & 77.30 & 88.00 & 102.60 & 131.20 & 115.10 & 85.60 & 93.90 & 102.20 & 140.30 & 138.40 & 143.40 \\
\hline $\mathrm{Cl}$ & 308.75 & 132.05 & 101.65 & 165.3 & 166.25 & 130.15 & 135.85 & 128.25 & 267.9 & 198.55 & 308.75 \\
\hline $\mathrm{Cr}$ & 0.03 & 0.025 & 0.035 & 0.034 & 0.043 & 0.025 & 0.026 & 0.030 & 0.032 & 0.026 & 0.033 \\
\hline $\mathrm{Cu}$ & 0.002 & - & - & - & - & - & - & - & - & 0.006 & - \\
\hline $\mathrm{Fe}$ & 0.389 & 1.80 & 0.513 & 0.637 & 1.215 & 0.393 & 0.452 & 0.503 & 0.655 & 0.524 & 0.662 \\
\hline$K$ & 11.10 & 8.90 & 8.60 & 8.70 & 9.00 & 10.70 & 11.20 & 10.10 & 11.40 & 28.90 & 10.20 \\
\hline Li & 0.141 & 0.065 & 0.057 & 0.060 & 0.104 & 0.071 & 0.069 & 0.068 & 0.097 & 0.247 & 0.065 \\
\hline Mg & 103.10 & 73.00 & 66.60 & 77.2 & 76.10 & 77.80 & 81.80 & 74.00 & 83.00 & 283.50 & 96.30 \\
\hline$M n$ & 0.079 & - & - & - & - & - & - & - & - & 0.032 & - \\
\hline $\mathrm{Na}$ & 181.10 & 92.30 & 75.80 & 117.0 & 119.20 & 95.40 & 99.80 & 93.80 & 75.00 & 930.90 & 187.30 \\
\hline $\mathrm{Ni}$ & 0.003 & 0.005 & 0.005 & 0.007 & 0.01 & 0.005 & 0.004 & 0.005 & 0.006 & 0.005 & 0.006 \\
\hline $\mathrm{Sr}$ & 3.1 & 2.60 & 2.40 & 3.30 & 3.20 & 2.50 & 2.50 & 2.70 & 2.60 & 12.20 & 3.90 \\
\hline $\mathrm{Zn}$ & - & - & - & - & - & - & - & - & 3.50 & 0.010 & - \\
\hline
\end{tabular}



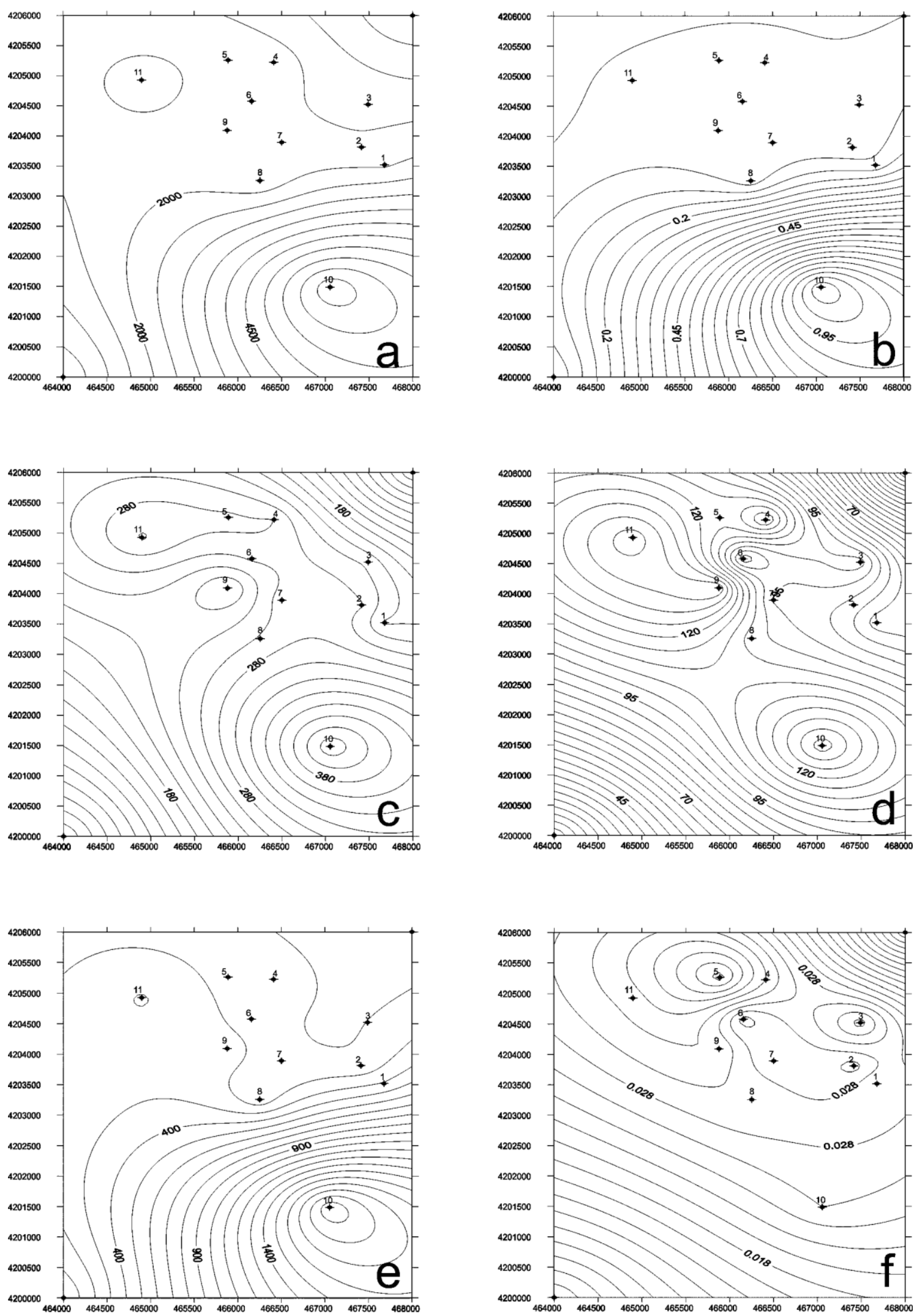

Figure 3. Iso-distrubition map of EC (a) and iso-concentration maps (in ppm) of $\mathrm{NH}_{3}$ (b), $\mathrm{SO}_{4}$ (c), $\mathrm{Ca}$ (d), $\mathrm{Cl}$ (e), $\mathrm{Cr}$ (f) of the groundwater samples 

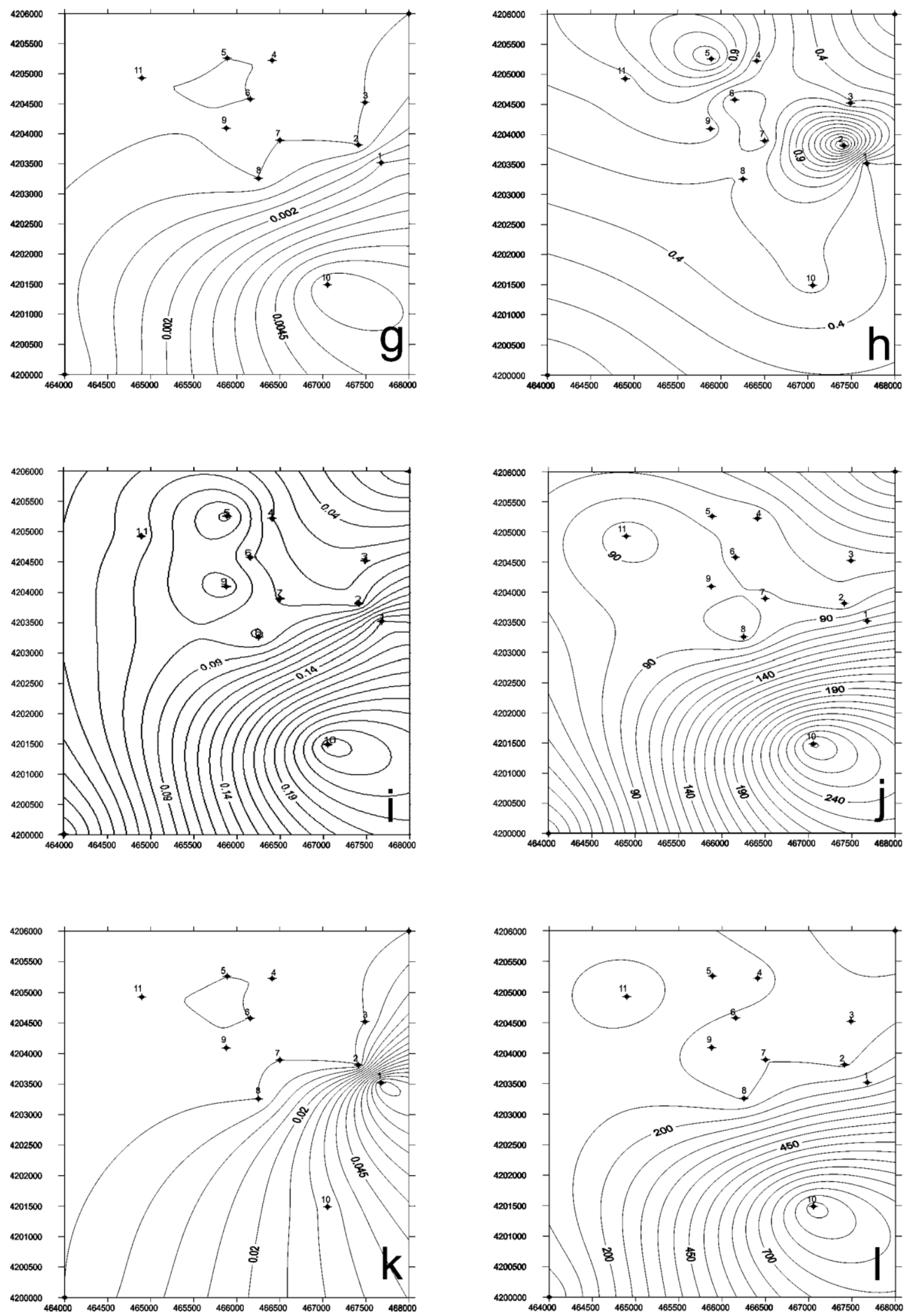

Figure 4. Iso-concentration maps (in ppm) of $\mathrm{Cu}(\mathrm{g})$, $\mathrm{Fe}(\mathrm{h}), \mathrm{Li}(\mathrm{i}), \mathrm{Mg}(\mathrm{j}), \mathrm{Mn}(\mathrm{k}), \mathrm{Na}(\mathrm{I})$ of the groundwater samples 

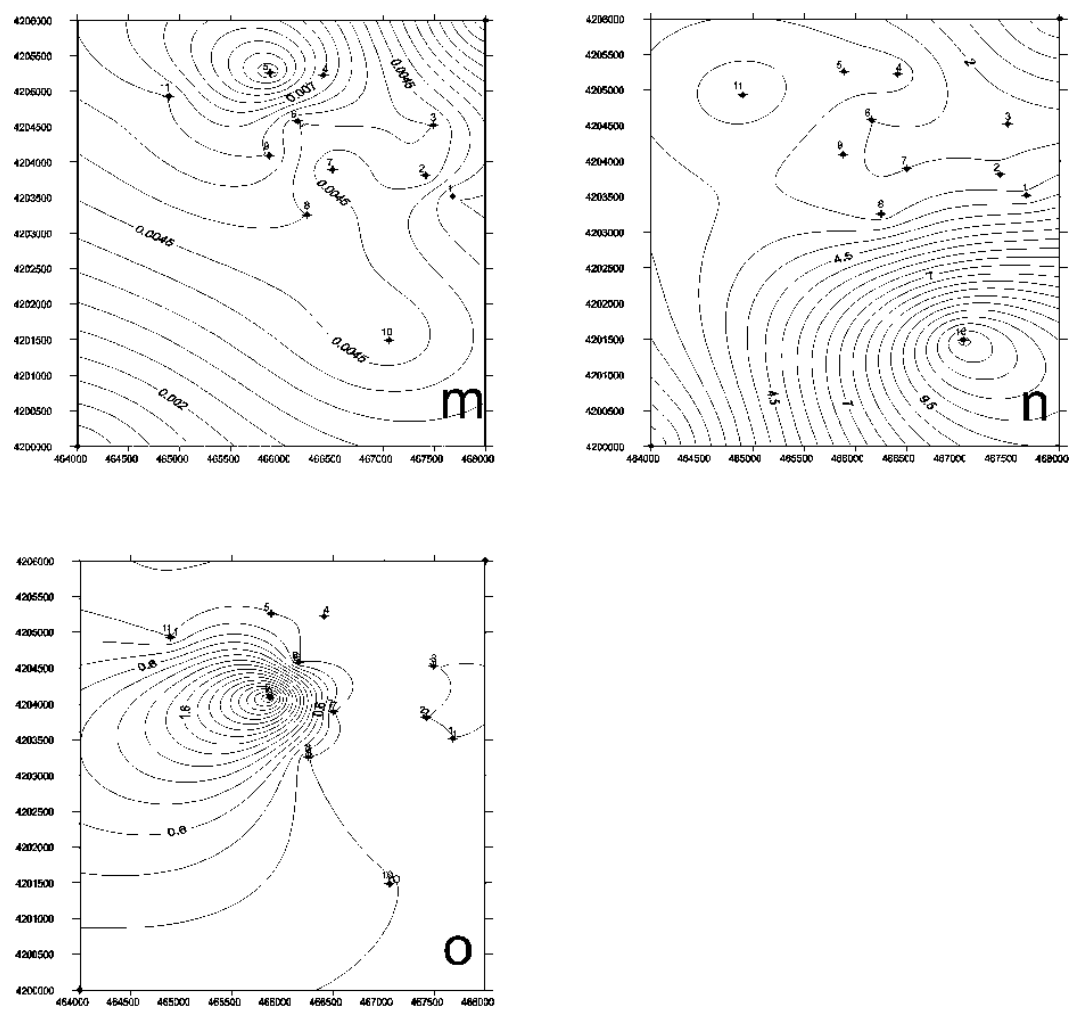

Figure 5. Iso-concentration maps (in ppm) of $\mathrm{Ni}(\mathrm{m}), \mathrm{Sr}(\mathrm{n}), \mathrm{Zn}(\mathrm{o})$ of the groundwater samples

Table 4. The results of rainy period analyses on the water samples (in ppm; except as noted)

\begin{tabular}{|c|c|c|c|c|c|c|c|c|c|c|c|}
\hline Sample No & 1 & 2 & 3 & 4 & 5 & 6 & 7 & 8 & 9 & 10 & 11 \\
\hline $\begin{array}{c}\text { Well } \\
\text { coordinate }(X)\end{array}$ & 467678 & 467414 & 467490 & 466411 & 465888 & 466157 & 466501 & 466252 & 465878 & 467055 & 464897 \\
\hline $\begin{array}{c}\text { Well } \\
\text { coordinate }(Y)\end{array}$ & 4203519 & 4203813 & 4204523 & 4205223 & 4205259 & 4204578 & 4203893 & 4203257 & 4204093 & 4201487 & 4204928 \\
\hline pH & 7.16 & 7.21 & 7.01 & 7.04 & 6.76 & 6.8 & 6.83 & 6.82 & 6.9 & 7.1 & 6.95 \\
\hline $\mathrm{EC}\left(\mu \mathrm{mhos} \mathrm{cm}^{-1}\right)$ & 4380 & 2177 & 1842 & 1942 & 1930 & 1860 & 2032 & 1610 & 1899 & 2610 & 3042 \\
\hline TDS & 2790 & 1387 & 1173 & 1237 & 1229 & 1185 & 1294 & 1025 & 1210 & 1662 & 1938 \\
\hline T Alkalinity & 441.75 & 482 & 492.9 & 502.2 & 492.9 & 487 & 521 & 478.95 & 437.1 & 500 & 437.1 \\
\hline $\begin{array}{l}\text { T Hardness } \\
(\mathrm{Fr})\end{array}$ & 119 & 118 & 82 & 87 & 85 & 90 & 93 & 68 & 84 & 100 & 102 \\
\hline Turbidity (NTU) & 3.9 & 6.2 & 0.93 & 4.6 & 0.4 & 1.2 & 0.7 & 3.03 & 0.6 & 0.6 & 2.6 \\
\hline $\mathrm{NH}_{3}$ & 0.26 & $<0.06$ & $<0.06$ & $<0.06$ & $<0.06$ & $<0.06$ & $<0.06$ & $<0.06$ & $<0.06$ & $<0.06$ & $<0.06$ \\
\hline $\mathrm{NO}_{3}$ & 3.8 & 8.7 & 4.2 & 5 & 4.7 & 11.2 & 9.3 & 6.8 & 6.7 & 0.7 & 1.4 \\
\hline $\mathrm{SO}_{4}$ & 358.36 & 281.47 & 263.67 & 275.93 & 304.04 & 259.5 & 283.12 & 208.19 & 180.01 & 415 & 301.11 \\
\hline B & 0.20 & 0.22 & 0.21 & 0.204 & 0.206 & 0.23 & 0.238 & 0.218 & 0.219 & 0.201 & 0.196 \\
\hline $\mathrm{Ca}$ & 138.6 & 125.4 & 194.04 & 205.92 & 229.68 & 127 & 183 & 162.36 & 194.04 & 218.25 & 221.76 \\
\hline $\mathrm{Cl}$ & 940.5 & 235 & 153.45 & 186.12 & 175.23 & 127.3 & 141.5 & 101.97 & 288.09 & 285 & 653.75 \\
\hline Co & 0.003 & 0.003 & 0.003 & 0.003 & 0.005 & 0.003 & 0.003 & 0.004 & 0.005 & 0.004 & 0.005 \\
\hline $\mathrm{Cr}$ & 0.142 & 0.137 & 0.135 & 0.132 & 0.168 & 0.157 & 0.153 & 0.186 & 0.142 & 0.161 & 0.169 \\
\hline $\mathrm{Cu}$ & 0.005 & - & - & - & - & - & - & - & - & 0.006 & - \\
\hline $\mathrm{Fe}$ & 6.422 & 12.41 & 7.822 & 8.819 & 11.53 & 6.381 & 6.425 & 9.267 & 11.28 & 10.5 & 13.35 \\
\hline $\mathrm{K}$ & 10.08 & 8.83 & 9.70 & 11.60 & 10.70 & 11.20 & 10.42 & 10.00 & 10.40 & 11.57 & 10.20 \\
\hline Li & 0.353 & 0.038 & 0.032 & 0.31 & 0.027 & 0.044 & 0.041 & 0.049 & 0.079 & 0.03 & 0.028 \\
\hline Mg & 201.71 & 154.92 & 80.44 & 84.15 & 65.59 & 115 & 113 & 65.59 & 85.39 & 106 & 111.38 \\
\hline$M n$ & 0.062 & - & - & - & - & - & - & 0.007 & 0.002 & - & 0.055 \\
\hline $\mathrm{Na}$ & 402.5 & 103.73 & 86.2 & 126.27 & 128.74 & 97.29 & 80.73 & 88.78 & 87.16 & 198.49 & 228.45 \\
\hline $\mathrm{Ni}$ & 0.045 & 0.042 & 0.058 & 0.065 & 0.087 & 0.063 & 0.068 & 0.073 & 0.086 & 0.087 & 0.108 \\
\hline $\mathrm{Sr}$ & 2.988 & 2.23 & 2.543 & 2.846 & 2.89 & 2.74 & 2.42 & 2.09 & 2.20 & 2.84 & 3.47 \\
\hline $\mathbf{V}$ & 0.032 & 0.003 & 0.003 & 0.002 & - & 0.005 & 0.005 & - & 0.007 & 0.010 & 0.015 \\
\hline $\mathrm{Zn}$ & - & - & - & - & 0.503 & - & - & 0.206 & 3.263 & 0.304 & 0.060 \\
\hline
\end{tabular}


Table 4 shows the results of rainy period analyses (March 2011). The EC of groundwater in the area ranged from $1610 \mu$ mhos $\mathrm{cm}^{-1}$ (Sample 8) to $4380 \mu$ mhos $\mathrm{cm}^{-1}$ (Sample 1). The total dissolved solids (TDS) of groundwater in the area ranged from $1025 \mathrm{ppm}$ (Sample 8) to $2790 \mathrm{ppm}$ (Sample 1). $\mathrm{SO}_{4}$ concentrations ranged from $180 \mathrm{ppm}$ (Sample 9) to $415 \mathrm{ppm}$ (Sample 10). The amount of Fe ranged from $6.381 \mathrm{ppm}$ (Sample 6) to $13.35 \mathrm{ppm}$ (Sample 11), while Li values ranged from $0.027 \mathrm{ppm}$ (Sample 5) to $0.079 \mathrm{ppm}$ (Sample 9). Mg concentrations fell between 65.59 ppm (Sample 5) and 201.71 ppm (Sample 1), whereas $\mathrm{Ni}$ fell between $0.042 \mathrm{ppm}$ (Sample 2) and $0.108 \mathrm{ppm}$ (Sample 11). Sr concentration was defined at levels ranging from $2.09 \mathrm{ppm}$ (Sample 8) to $3.47 \mathrm{ppm}$ (Sample 11). In five water samples, Zn showed concentrations ranging from $0.06 \mathrm{ppm}$ (Sample 11) to $3.263 \mathrm{ppm}$ (Sample 9). Meanwhile, Mn was attained in only four samples the concentration of which (Sample 1) reached $0.062 \mathrm{ppm}$. Lastly; $\mathrm{Cu}$ appeared in two samples only: Sample $1(0.005 \mathrm{ppm})$ and Sample $10(0.006 \mathrm{ppm})$. Also, the distributions of the analyses obtained from water samples collected in the study area are given in Figure 6 - 8 .

\section{Discussion}

In the studies and water analyzes carried out in the scope of this study, it was observed that the industrial area, where approximately $4,000 \mathrm{~m}^{3}$ of liquid waste is discharged and particularly metals, chemicals and machinery manufacturing exist, affect the quality of the groundwater. It was also determined that the geological features also have an effect on groundwater in the region.

\subsection{Evaluation of Hydrochemical Properties and its Distribution on the Area}

According to the analysis results of dry period, Sample 1 had the highest concentrations of $\mathrm{B}, \mathrm{Cl}$, and $\mathrm{Mn}$; Sample 2, Fe; Sample 4, $\mathrm{NO}_{3}$; Sample 5, $\mathrm{Cr}$, and Ni; Sample 7, total alkalinity; Sample 8, pH; Sample 9, Zn, and $\mathrm{NO}_{3}$; Sample 10, EC, total hardness, turbidity, $\mathrm{NH}_{3}, \mathrm{SO}_{4}, \mathrm{Cu}, \mathrm{K}, \mathrm{Li}, \mathrm{Mg}, \mathrm{Na}$, and $\mathrm{Sr}$; and Sample 11, $\mathrm{Ca}$, and $\mathrm{Cl}$ (Table 3). In respect to the analysis results of rainy period, Sample 1 had the highest concentrations of EC, $\mathrm{NH}_{3}, \mathrm{Cl}, \mathrm{Li}, \mathrm{Na}, \mathrm{Mg}, \mathrm{Mn}$, and V; Sample 2, turbidity, $\mathrm{pH}$, and total hardness; Sample 4, K; Sample 5, Ca; Sample 6, $\mathrm{NO}_{3}$; Sample 7, total alkalinity and B; Sample 8, Cr; Sample 9, Zn; Sample 10, $\mathrm{SO}_{4}$ and $\mathrm{Cu}$; and Sample 11, Fe, Sr, and $\mathrm{Ni}$ (Table 4).

According to the analysis results of dry period, the north-eastern part of the OIZ contained $\mathrm{EC}, \mathrm{NH}_{3} \mathrm{SO}_{4}$, $\mathrm{Ca}, \mathrm{Cl}, \mathrm{Cu}, \mathrm{Li}, \mathrm{Mg}, \mathrm{Na}$, and $\mathrm{Sr}$ in high density; the northern part, $\mathrm{Cr}$, and $\mathrm{Ni}$ in high density; the eastern part, $\mathrm{Fe}$, and $\mathrm{Mn}$ in high density; and in the central part, high densities of Zn. Figure 3-5 shows a concentration distribution map. In respect to the analysis results of rainy period, the eastern part of the OIZ contained $\mathrm{Cl}, \mathrm{Li}, \mathrm{Mg}, \mathrm{Mn}, \mathrm{Na}, \mathrm{V}$, and $\mathrm{NH}_{3}$ in high density; the north-western part, $\mathrm{Co}, \mathrm{Fe}, \mathrm{Ni}$, and $\mathrm{Sr}$ in high density; the south-western part, $\mathrm{Cu}$ and $\mathrm{SO}_{4}$ in high density; in the area extending from the northwest to the southeast, a high density of $\mathrm{Cr}$; and in the central part, high densities of $\mathrm{Ca}$ and $\mathrm{Zn}$. Figure 6-8 shows a concentration distribution map. The area on which $\mathrm{Ca}$ and $\mathrm{SO}_{4}$ focus at Figure 3 and 4 corresponds to the area where the Aslimyayla formation.

\subsection{Evaluation of Water Quality}

The Piper (1944) diagram was used to evaluate the water quality of groundwater samples taken from the study area (Figure 9). Also studies to use the waters for irrigation in agriculture were examined with the Wilcox (1955) diagram (Figure 10).

At the Piper diagram of the water samples in dry period, 10 numbered sample plots into 7 zone, other samples plot into 9 zone (Figure 9a). At evaluation of water analysis belonging to rainy period, 11 numbered sample plots into 6 zone, 6,7 and 8 numbered samples plot into 5 zone and other samples plot into 9 zone (Figure 9b). The water plotting in 7. District are classified as "water, non-carbonate alkalinity of which are more than carbonate alkalinity". These waters are also waters with $\mathrm{NaCl}, \mathrm{NaSO} 4$ and $\mathrm{KCl}$ and "water, non-carbonate alkalinity of which are more than $50 \% "$. Alkalis and strong acids are dominant. The waters that plot into 9 zone are "mixed compound waters, none of the ions of which exceeds 50\%". At waters plotting in 6. District "non-carbonate hardness is higher than 50\%". These waters are the waters with $\mathrm{CaSO}_{4}$ and $\mathrm{MgSO}_{4}$. At waters plotting in 5 . District "carbonate hardness is higher than $50 \% "$. These waters are waters with $\mathrm{CaCO}_{3}$ and $\mathrm{MgCO}_{3}$. 

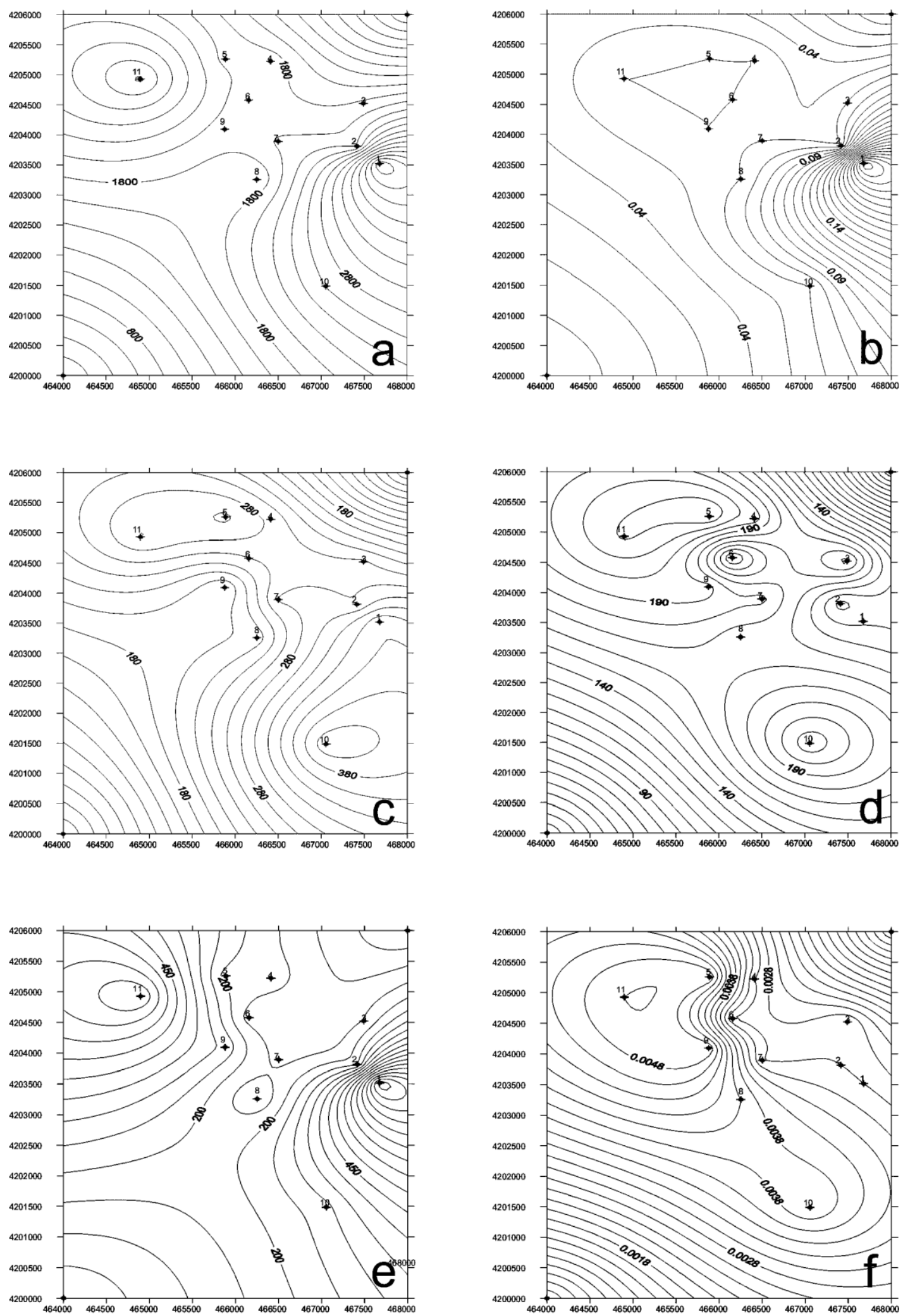

Figure 6. Iso-distrubition map of EC (a) and iso-concentration maps (in ppm) of $\mathrm{NH}_{3}$ (b), $\mathrm{SO}_{4}$ (c), $\mathrm{Ca}$ (d), $\mathrm{Cl}(\mathrm{e}), \mathrm{Co}(\mathrm{f})$ of the groundwater samples 

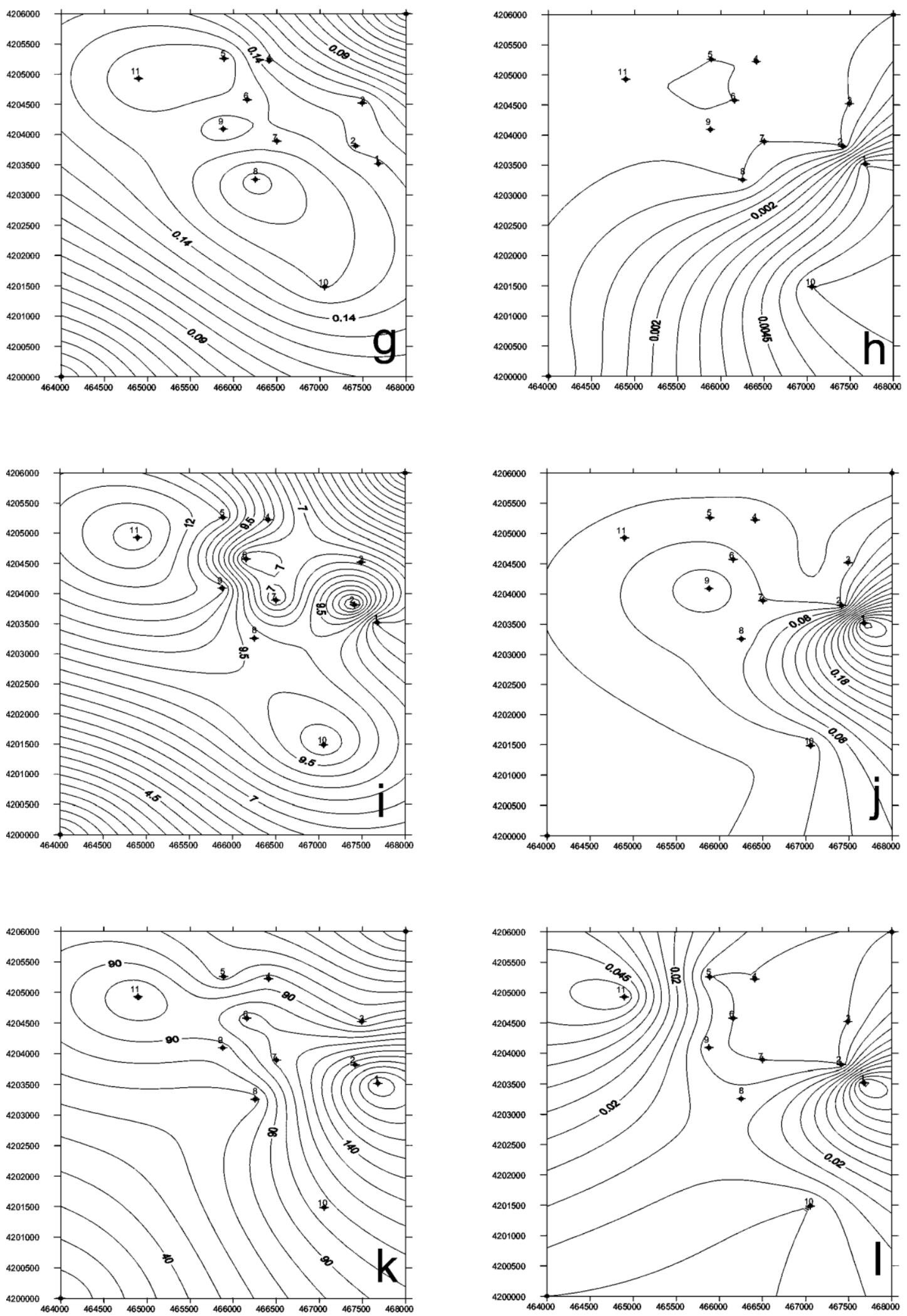

Figure 7. Iso-concentration maps (in ppm) of $\mathrm{Cr}(\mathrm{g}), \mathrm{Cu}(\mathrm{h}), \mathrm{Fe}(\mathrm{i}), \mathrm{Li}(\mathrm{j}), \mathrm{Mg}(\mathrm{k}), \mathrm{Mn}(\mathrm{I})$ of the groundwater samples. 

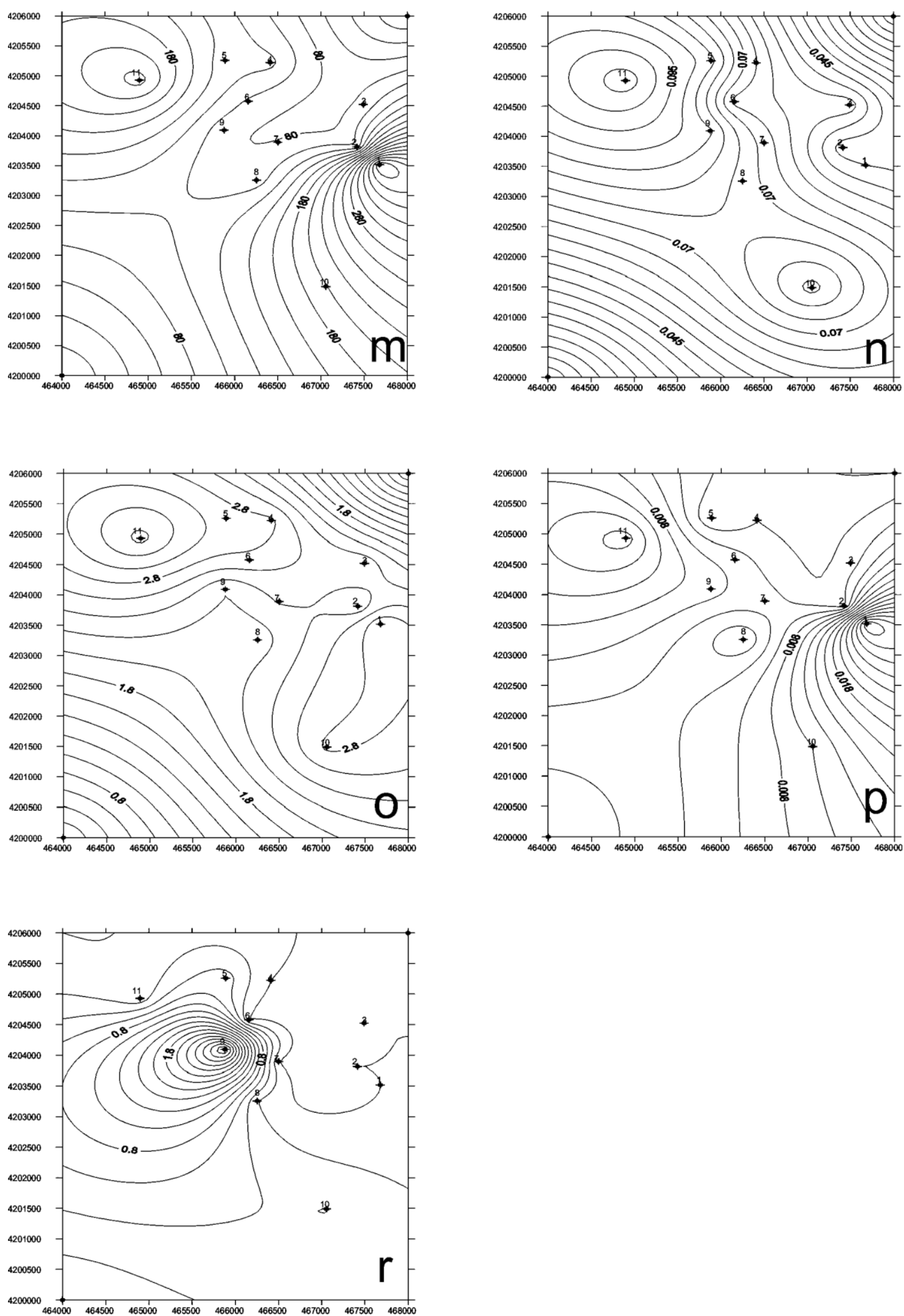

Figure 8. Iso-concentration maps (in ppm) of $\mathrm{Na}(\mathrm{m}), \mathrm{Ni}(\mathrm{n}), \mathrm{Sr}(\mathrm{o}), \mathrm{V}(\mathrm{p}), \mathrm{Zn}(\mathrm{r})$ of the groundwater samples 


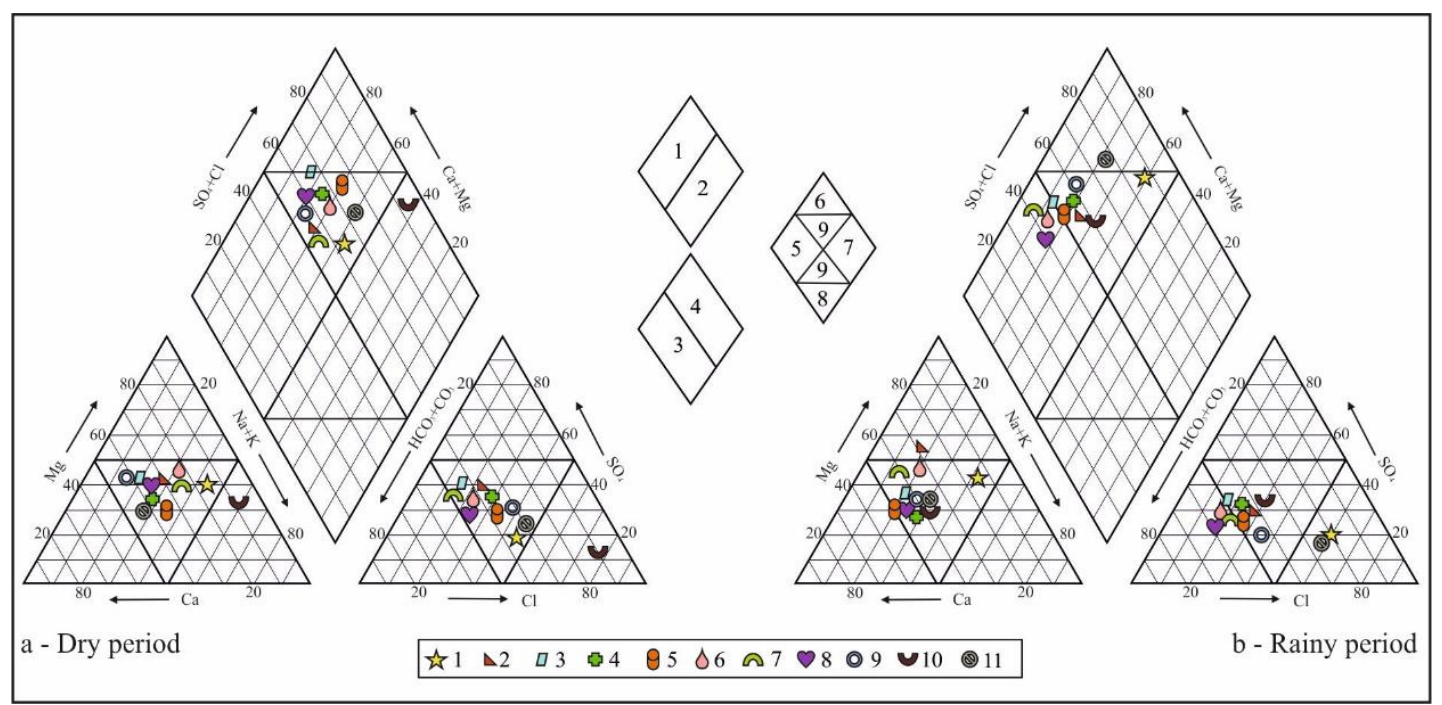

Figure 9. Piper diagram of the water samples

The Wilcox diagram distribution of water samples from dry period was made in order to evaluate the use of the waters in the study area for irrigation. Accordingly, it was determined that 10 numbered sample is classified as "not appropriate", 11 numbered sample is classified as "suspicious-not appropriate" and the other samples are classified as "well-used" for irrigation (Figure 10a). It was determined that 2, 7 and 10 numbered samples of rainy period are classified as "suspicious-not appropriate", 1 and 11 numbered samples of rainy period are classified as "not appropriate" and the other samples of rainy period are classified as "well-used" (Figure 10b).

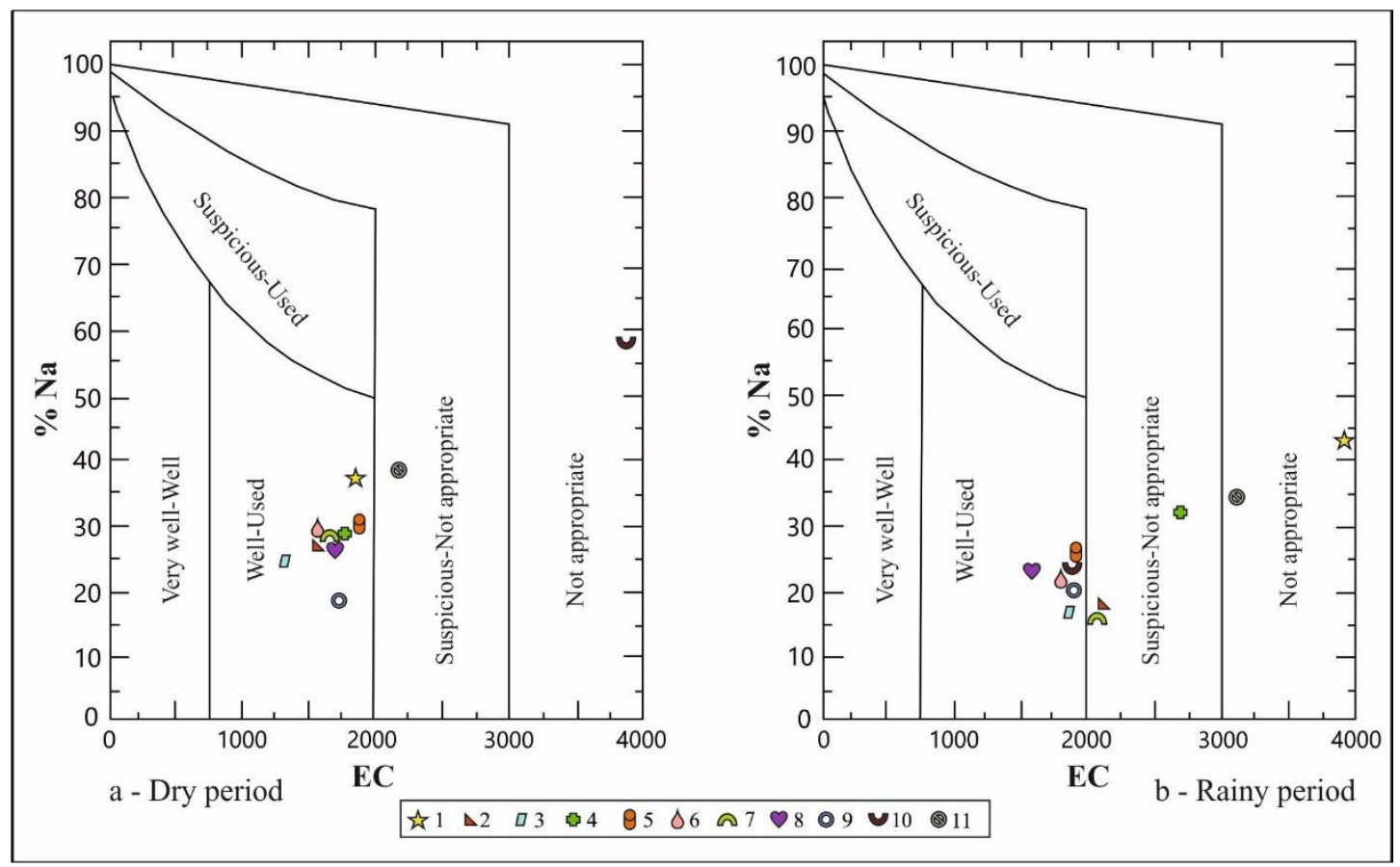

Figure 10. Wilcox diagram of the water samples

\subsection{Evaluation of Contamination}

The results of the two period analysis were compared in terms of potability in respect to limiting values to the maximum contamination level (MCL) according to Guidelines for Drinking-Water Quality of the World Health Organization (WHO, 2011), the National Primary Drinking Water Regulations of the U.S. 
Environmental Protection Agency (EPA, 2009), and European Communities (Drinking Water) Regulations (EC, 2007) (Table 5).

Table 5. Water samples exceeding (in ppm) the quideline values of the WHO (2011), the MCL of the EPA (2009) and the indicator parameters of the EC (2007) Standards ${ }^{*}$

\begin{tabular}{|c|c|c|c|c|c|c|}
\hline Elements & WHO & Sample No & EPA & Sample No & EC & Sample No \\
\hline \multirow{2}{*}{$\mathrm{NO}_{3}$} & \multirow{2}{*}{50} & & \multirow{2}{*}{10} & $\underline{3}, \underline{4}, \underline{9}, \underline{10}$ & \multirow{2}{*}{50} & \\
\hline & & & & 6 & & \\
\hline \multirow{2}{*}{$\mathrm{SO}_{4}$} & \multirow{2}{*}{250} & $\underline{2}, \underline{4}, \underline{5}, \underline{6}, \underline{7}, \underline{8}, \underline{10}, \underline{11}$ & \multirow{2}{*}{250} & $\underline{2}, \underline{4}, \underline{5}, \underline{6}, \underline{7}, \underline{8}, \underline{10}, \underline{11}$ & \multirow{2}{*}{250} & $\underline{2}, \underline{4}, \underline{5}, \underline{6}, \underline{7}, \underline{8}, \underline{10}, \underline{11}$ \\
\hline & & $1,2,3,4,5,6,7,10,11$ & & $1,2,3,4,5,6,7,10,11$ & & $1,2,3,4,5,6,7,10,11$ \\
\hline \multirow{2}{*}{$\mathrm{Cl}$} & \multirow{2}{*}{250} & $\underline{1}, \underline{9}, \underline{11}$ & 250 & $\underline{1}, \underline{9}, \underline{11}$ & \multirow{2}{*}{250} & $\underline{1}, \underline{9}, \underline{11}$ \\
\hline & & $1,9,10,11$ & SMCL & $1,9,10,11$ & & $1,9,10,11$ \\
\hline $\mathrm{Cr}$ & 0.05 & $1,2,3,4,5,6,7,8,9,10,11$ & 0.1 & $1,2,3,4,5,6,7,8,9,10,11$ & 0.05 & $1,2,3,4,5,6,7,8,9,10,11$ \\
\hline \multirow{2}{*}{$\mathrm{Fe}$} & \multirow{2}{*}{ - } & & 0.3 & $\underline{1}, \underline{2}, \underline{3}, \underline{6}, \underline{7}, \underline{8}, \underline{9}, \underline{10}, \underline{11}$ & \multirow{2}{*}{0.2} & $\underline{1}, \underline{2}, \underline{3}, \underline{4}, \underline{5}, \underline{6}, \underline{7}, \underline{8}, \underline{9}, \underline{10}, \underline{11}$ \\
\hline & & & SMCL & $1,2,3,4,5,6,7,8,9,10,11$ & & $1,2,3,4,5,6,7,8,9,10,11$ \\
\hline \multirow{2}{*}{$\mathrm{Mn}$} & \multirow{2}{*}{0.1} & & 0.05 & $\underline{1}$ & \multirow{2}{*}{0.05} & $\underline{\underline{1}}$ \\
\hline & & & SMCL & 1,11 & & 1,11 \\
\hline $\mathrm{Na}$ & 200 & 1,11 & 200 & 1,11 & 200 & 1,11 \\
\hline $\mathrm{Ni}$ & 0.02 & $1,2,3,4,5,6,7,8,9,10,11$ & - & & 0.02 & $1,2,3,4,5,6,7,8,9,10,11$ \\
\hline \multirow{2}{*}{$\mathrm{Zn}$} & \multirow[b]{2}{*}{3} & $\underline{9}$ & 5 & & \multirow{2}{*}{ - } & \\
\hline & & 9 & SMCL & & & \\
\hline
\end{tabular}

* Note: 1- The underlined numbers are of August 2010; while the others are of March 2011

2- SMCL: Secondary Maxsimum Contaminant Level of EPA (2009)

In respect to Table 5; during August 2010 period, all samples showed levels of $\mathrm{Mg}$ in excessive of the MCL, while nearly all samples had excessive levels of $\mathrm{SO}_{4}, \mathrm{Ca}$, and $\mathrm{Fe}$, four samples excessive level of $\mathrm{NO}_{3}$, three samples excessive $\mathrm{Cl}$, one sample excessive $\mathrm{Mn}$, and $\mathrm{Zn}$. During March 2011 period all samples showed levels of $\mathrm{Cr}$, Fe, and $\mathrm{Mg}$ in excessive of the $\mathrm{MCL}$, while nearly all samples had excessive levels of $\mathrm{Ca}$ and $\mathrm{Ni}$. Nine samples had excessive $\mathrm{SO}_{4}$, four samples excessive $\mathrm{Cl}$, two samples excessive $\mathrm{Na}$, and $\mathrm{Mn}$, and one sample excessive $\mathrm{NO}_{3}$, and $\mathrm{Zn}$. In summary; almost all samples had high level of concentrations of $\mathrm{SO}_{4}, \mathrm{Ca}, \mathrm{Mg}$, and $\mathrm{Fe}$ in both periods. It was determined that $\mathrm{Cr}$, $\mathrm{Na}$ and $\mathrm{Ni}$ concentrations exceeded $\mathrm{MCL}$ values only in rainy period.

Nitrate $\left(\mathrm{NO}_{3}\right)$ exceeds $\mathrm{MCL}$ limit at four samples in the dry period, at one sample in the rainy season. High $\mathrm{NO}_{3}$ concentrations are due to the fertilizers used in agricultural activities in the dry period from the agricultural areas around the OIZ. The presence of $\mathrm{NO}_{3}$ in the rainy period is due to the sewage system and point contamination.

The fact that $\mathrm{Cr}$, Fe, $\mathrm{Mg}$, and $\mathrm{Ni}$ originating mostly from industrial contamination exceed the $\mathrm{MCL}$ in nearly all samples suggests that contamination has occurred throughout the OIZ. In support of this suggestion, $\mathrm{Co}, \mathrm{Fe}, \mathrm{Li}$, and $\mathrm{Sr}$ appeared in all wells, while $\mathrm{Mn}, \mathrm{V}$, and $\mathrm{Zn}$ appeared in some water samples in different concentrations.

Rising levels of components such as $\mathrm{Ca}, \mathrm{Cl}, \mathrm{Na}$, and $\mathrm{SO}_{4}$ in the $\mathrm{OIZ}^{\prime}$ s water should be seen as a result of the interaction of salty components $\mathrm{Na}$ and $\mathrm{Cl}$, the hardness of which are quite low and which dissolve easily in water. Meanwhile, $\mathrm{Ca}$ and $\mathrm{SO}_{4} \cdot 2 \mathrm{H}_{2} \mathrm{O}$ as components of gypsum lithology appeared in Aslımyayla formation and groundwater. As the results of the analyses showed, nearly all samples had concentration levels of $\mathrm{Ca}$ and $\mathrm{SO}_{4}$ that exceeded MCL. At the same time, the $\mathrm{EC}$ distribution map and $\mathrm{Ca}, \mathrm{Cl}, \mathrm{Na}$, and $\mathrm{SO}_{4}$ concentration maps resembled each other, suggesting a naturally occurring contamination state due to the OIZ's geology and which stems from the interaction of water and rock.

\subsection{Evaluation of the Statistical Analysis of the Groundwater}

The analysis results of groundwater samples collected during dry and wet seasons were evaluated statistically so that they will be of two seasons (Table 6 and 8 ). All evaluations were realized $95 \%$ relevance level. Within this context, correlation coefficient and cluster analyses were conducted (Table 7 and 9 , Figure 11 and 12). 
Table 6. Statistical evaluation of the water samples of dry period

\begin{tabular}{ccccccc}
\hline & Mean & $\begin{array}{c}\text { Standard } \\
\text { Error }\end{array}$ & $\begin{array}{c}\text { Standard } \\
\text { Deviation }\end{array}$ & Test t value & Lower Limit & Upper Limit \\
\hline pH & 7,04 & 0,06 & 0,19 & 120,09 & 6,91 & 7,17 \\
\hline EC & 2195,73 & 474,96 & 1575,25 & 4,62 & 1137,46 & 3254,00 \\
\hline TDS & 1398,64 & 302,52 & 1003,33 & 4,62 & 724,59 & 2072,68 \\
\hline T Alk. & 474,27 & 8,17 & 27,10 & 58,05 & 456,07 & 492,48 \\
\hline T Hard. & 90,00 & 8,02 & 26,59 & 11,23 & 72,14 & 107,86 \\
\hline Turb. & 4,32 & 2,71 & 8,98 & 1,60 & $-1,71$ & 10,35 \\
\hline NH3 & 0,12 & 0,10 & 0,32 & 1,25 & $-0,10$ & 0,34 \\
\hline NO3 & 9,01 & 1,04 & 3,46 & 8,64 & 6,69 & 11,33 \\
\hline SO4 & 273,50 & 18,62 & 61,75 & 14,69 & 232,02 & 314,99 \\
\hline $\mathbf{B}$ & 0,22 & 0,01 & 0,04 & 20,88 & 0,20 & 0,25 \\
\hline $\mathbf{C a}$ & 110,73 & 7,28 & 24,15 & 15,21 & 94,50 & 126,95 \\
\hline $\mathbf{C l}$ & 185,77 & 22,73 & 75,37 & 8,17 & 135,13 & 236,41 \\
\hline $\mathbf{C r}$ & 0,03 & 0,00 & 0,01 & 18,74 & 0,03 & 0,03 \\
\hline $\mathbf{C u}$ & 0,004 & 0,002 & 0,003 & 2,000 & $-0,021$ & 0,029 \\
\hline $\mathbf{F e}$ & 0,70 & 0,13 & 0,43 & 5,44 & 0,42 & 0,99 \\
\hline $\mathbf{K}$ & 11,71 & 1,75 & 5,80 & 6,70 & 7,81 & 15,60 \\
\hline $\mathbf{L i}$ & 0,09 & 0,02 & 0,06 & 5,59 & 0,06 & 0,13 \\
\hline $\mathbf{M g}$ & 99,31 & 18,69 & 61,98 & 5,31 & 57,67 & 140,95 \\
\hline $\mathbf{M n}$ & 0,06 & 0,02 & 0,03 & 2,36 & $-0,24$ & 0,35 \\
\hline $\mathbf{N a}$ & 187,96 & 75,16 & 249,29 & 2,50 & 20,49 & 355,44 \\
\hline $\mathbf{N i}$ & 0,01 & 0,00 & 0,00 & 10,17 & 0,00 & 0,01 \\
\hline $\mathbf{S r}$ & 3,73 & 0,86 & 2,85 & 4,34 & 1,82 & 5,64 \\
\hline $\mathbf{Z n}$ & 1,76 & 1,75 & 2,47 & 1,01 & $-20,42$ & 23,93 \\
\hline
\end{tabular}

In the groundwater samples of dry period: TDS-EC; T.Hard-EC and TDS; Turb.-EC, TDS and T.Hard.; $\mathrm{NH}_{3-}$ EC, TDS, T.Hard. and Turb.; $\mathrm{SO}_{4}-\mathrm{EC}$, TDS, T.Hard. and $\mathrm{NH}_{3}$; K-EC,TDS, T.Hard., Turb. and $\mathrm{NH}_{3}$; Li- EC,TDS, T.Hard., Turb., $\mathrm{NH}_{3}$ and $\mathrm{K}$; Mg- EC,TDS, T.Hard., Turb., $\mathrm{NH}_{3}, \mathrm{SO}_{4}, \mathrm{~K}$ and $\mathrm{Li}$; $\mathrm{Na}-\mathrm{EC}$,TDS, T.Hard., Turb., $\mathrm{NH}_{3}$, $\mathrm{SO}_{4}, \mathrm{~K}, \mathrm{Li}$ and $\mathrm{Mg}$; Sr- EC,TDS, T.Hard., Turb., $\mathrm{NH}_{3}, \mathrm{SO}_{4}, \mathrm{~K}, \mathrm{Li}, \mathrm{Mg}$ and $\mathrm{Ni}$ element pairs have very high positive correlation (Table 7). Only Cl-T.Alkalinity and $\mathrm{Cl}-\mathrm{NO}_{3}$ element pairs show a high negative and moderate negative correlation in order.

Table 7. Correlation coefficients between the element pairs of the water samples of dry period

\begin{tabular}{|c|c|c|c|c|c|c|c|c|c|c|c|c|c|c|c|c|c|c|c|c|}
\hline & $\mathrm{pH}$ & EC & TDS & T Alk. & T Hard. & Turb. & $\mathrm{NH} 3$ & $\mathrm{NO} 3$ & $\mathrm{SO} 4$ & B & $\mathrm{Ca}$ & $\mathrm{Cl}$ & $\mathrm{Cr}$ & $\mathrm{Fe}$ & $\mathrm{K}$ & $\mathrm{Li}$ & $\mathrm{Mg}$ & $\mathrm{Na}$ & $\mathrm{Ni}$ & $\mathrm{Sr}$ \\
\hline $\mathrm{pH}$ & 1,00 & & & & & & & & & & & & & & & & & & & \\
\hline EC & 0,04 & 1,00 & & & & & & & & & & & \multicolumn{8}{|c|}{ Very high positive correlation ( 0.85 to 1.00 ) } \\
\hline TDS & 0,04 & 1,00 & 1,00 & & & & & & & & & 0,82 & \multicolumn{8}{|c|}{ High positive correlation ( 0.60 to 0.85 ) } \\
\hline T Alk. & $-0,05$ & $-0,03$ & $-0,03$ & 1,00 & & & & & & & & & \multicolumn{8}{|c|}{ Moderate positive correlation ( 0.45 to 0.60 ) } \\
\hline THard. & $-0,04$ & 0,98 & 0,98 & 0,06 & 1,00 & & & & & & & & \multicolumn{8}{|c|}{ Low positive correlation ( 0.30 to 0.45 ) } \\
\hline Turb. & 0,16 & 0,97 & 0,97 & $-0,01$ & 0,94 & 1,00 & & & & & & & \multicolumn{8}{|c|}{ No correlation $(-0.30$ to 0.30$)$} \\
\hline $\mathrm{NH} 3$ & 0,08 & 0,99 & 0,99 & $-0,01$ & 0,97 & 0,98 & 1,00 & & & & & & \multicolumn{8}{|c|}{ Low negative correlation $(-0.45$ to -0.30$)$} \\
\hline NO3 & $-0,35$ & 0,10 & 0,10 & $-0,03$ & 0,19 & 0,08 & 0,14 & 1,00 & & & & & \multicolumn{8}{|c|}{ Moderate negative correlation (- 0.60 to -0.45$)$} \\
\hline SO4 & $-0,09$ & 0,88 & 0,88 & 0,31 & 0,90 & 0,84 & 0,86 & 0,11 & 1,00 & & & & \multicolumn{8}{|c|}{ High negative correlation $(-0.85$ to -0.60$)$} \\
\hline B & 0,16 & 0,29 & 0,29 & $-0,30$ & 0,21 & 0,31 & 0,33 & $-0,17$ & $-0,01$ & 1,00 & & & & & & & & & & \\
\hline $\mathrm{Ca}$ & $-0,42$ & 0,44 & 0,44 & $-0,32$ & 0,52 & 0,30 & 0,36 & 0,49 & 0,41 & $-0,22$ & 1,00 & & & & & & & & & \\
\hline $\mathrm{Cl}$ & $-0,03$ & 0,17 & 0,17 & $-0,63$ & 0,11 & 0,07 & 0,08 & $-0,49$ & $-0,06$ & 0,23 & 0,37 & 1,00 & & & & & & & & \\
\hline $\mathrm{Cr}$ & $-0,38$ & $-0,26$ & $-0,26$ & $-0,20$ & $-0,21$ & $-0,35$ & $-0,30$ & 0,31 & $-0,19$ & 0,24 & 0,34 & 0,11 & 1,00 & & & & & & & \\
\hline $\mathrm{Fe}$ & 0,23 & $-0,14$ & $-0,14$ & 0,17 & $-0,06$ & $-0,02$ & $-0,15$ & $-0,09$ & $-0,01$ & $-0,02$ & $-0,06$ & $-0,19$ & 0,13 & 1,00 & & & & & & \\
\hline $\mathrm{K}$ & 0,07 & 0,98 & 0,98 & $-0,01$ & 0,96 & 0,95 & 0,99 & 0,10 & 0,82 & 0,32 & 0,36 & 0,15 & $-0,37$ & $-0,23$ & 1,00 & & & & & \\
\hline Li & 0,13 & 0,91 & 0,91 & $-0,14$ & 0,86 & 0,89 & 0,91 & $-0,09$ & 0,67 & 0,63 & 0,24 & 0,32 & $-0,17$ & $-0,17$ & 0,92 & 1,00 & & & & \\
\hline $\mathrm{Mg}$ & 0,07 & 1,00 & 1,00 & $-0,06$ & 0,96 & 0,96 & 0,99 & 0,05 & 0,85 & 0,33 & 0,38 & 0,21 & $-0,30$ & $-0,19$ & 0,99 & 0,93 & 1,00 & & & \\
\hline $\mathrm{Na}$ & 0,06 & 1,00 & 1,00 & $-0,03$ & 0,97 & 0,97 & 0,99 & 0,06 & 0,88 & 0,31 & 0,39 & 0,17 & $-0,27$ & $-0,16$ & 0,98 & 0,91 & 1,00 & 1,00 & & \\
\hline $\mathrm{Ni}$ & $-0,53$ & $-0,08$ & $-0,08$ & 0,16 & 0,06 & $-0,15$ & $-0,12$ & 0,38 & 0,11 & 0,01 & 0,48 & $-0,09$ & 0,78 & 0,41 & $-0,19$ & $-0,12$ & $-0,15$ & $-0,11$ & 1,00 & \\
\hline $\mathrm{Sr}$ & 0,02 & 1,00 & 1,00 & $-0,02$ & 0,98 & 0,96 & 0,99 & 0,12 & 0,9 & 0,28 & 0,46 & 0,16 & $-0,22$ & $-0,13$ & 0,97 & 0,89 & 0,99 & 1,00 & $-0,04$ & 1,00 \\
\hline
\end{tabular}


$\mathrm{EC}, \mathrm{NH}_{3}, \mathrm{SO}_{4}$ show positive correlation in correlation analyses of dry season analyses, and In pair concentration maps belonging to $\mathrm{Li}, \mathrm{Mg}, \mathrm{Na}$ and $\mathrm{Sr}$ groundwater table also, In pair concentration maps belonging to $\mathrm{Li}, \mathrm{Mg}$, Na and $\mathrm{Sr}$ groundwater table exhibit similar distributions (Figure 3, 4 and 5). At the points of investigation area where groundwater concentration changes were observed, the pairs having very high correlations possess similar decrease and increase (Table 7). However, the fact that $\mathrm{Mg}$-Cr pairs have concentration changes in separate points supports negative correlation between these element pairs (Figure 3 and 4) (Table 7). In Figure 3 and 4, it was determined that $\mathrm{Ca}$ and Fe elements having scattered curves in correlation analyses did not possess any correlations (Table 7).

Table 8. Statistical evaluation of the water samples of rainy period

\begin{tabular}{|c|c|c|c|c|c|c|}
\hline & Mean & $\begin{array}{c}\text { Standard } \\
\text { Error }\end{array}$ & $\begin{array}{l}\text { Standard } \\
\text { Deviation }\end{array}$ & Test $t$ value & Lower Limit & Upper Limit \\
\hline $\mathrm{pH}$ & 6,96 & 0,05 & 0,15 & 150,06 & 6,86 & 7,07 \\
\hline EC & 2302,18 & 240,55 & 797,83 & 9,57 & 1766,19 & 2838,17 \\
\hline TDS & 1466,36 & 153,25 & 508,28 & 9,57 & 1124,90 & 1807,83 \\
\hline T Alk. & 479,35 & 8,58 & 28,46 & 55,86 & 460,23 & 498,47 \\
\hline T Hard. & 93,45 & 4,64 & 15,38 & 20,16 & 83,12 & 103,79 \\
\hline Turb. & 2,25 & 0,59 & 1,97 & 3,80 & 0,93 & 3,57 \\
\hline NH3 & 0,08 & 0,02 & 0,06 & 4,30 & 0,04 & 0,12 \\
\hline NO3 & 5,68 & 0,98 & 3,24 & 5,81 & 3,50 & 7,86 \\
\hline SO4 & 284,58 & 19,31 & 64,05 & 14,74 & 241,55 & 327,61 \\
\hline B & 0,21 & 0,00 & 0,01 & 53,15 & 0,20 & 0,22 \\
\hline $\mathrm{Ca}$ & 181,82 & 11,49 & 38,12 & 15,82 & 156,22 & 207,43 \\
\hline $\mathrm{Cl}$ & 298,90 & 78,86 & 261,56 & 3,79 & 123,18 & 474,62 \\
\hline Co & 0,00 & 0,00 & 0,00 & 13,67 & 0,00 & 0,00 \\
\hline $\mathrm{Cr}$ & 0,15 & 0,01 & 0,02 & 29,71 & 0,14 & 0,16 \\
\hline $\mathrm{Cu}$ & 0,01 & 0,00 & 0,00 & 11,00 & 0,00 & 0,01 \\
\hline $\mathrm{Fe}$ & 9,47 & 0,76 & 2,52 & 12,46 & 7,78 & 11,17 \\
\hline $\mathrm{K}$ & 10,43 & 0,25 & 0,82 & 41,97 & 9,87 & 10,98 \\
\hline Li & 0,09 & 0,04 & 0,12 & 2,62 & 0,01 & 0,17 \\
\hline $\mathrm{Mg}$ & 107,56 & 12,25 & 40,63 & 8,78 & 80,27 & 134,86 \\
\hline$M n$ & 0,03 & 0,02 & 0,03 & 2,01 & $-0,02$ & 0,08 \\
\hline $\mathrm{Na}$ & 148,03 & 29,34 & 97,32 & 5,04 & 82,65 & 213,41 \\
\hline $\mathrm{Ni}$ & 0,07 & 0,01 & 0,02 & 11,93 & 0,06 & 0,08 \\
\hline $\mathrm{Sr}$ & 2,66 & 0,12 & 0,41 & 21,50 & 2,38 & 2,94 \\
\hline $\mathbf{v}$ & 0,01 & 0,00 & 0,01 & 2,88 & 0,00 & 0,02 \\
\hline $\mathrm{Zn}$ & 0,87 & 0,60 & 1,35 & 1,44 & $-0,81$ & 2,54 \\
\hline
\end{tabular}

In the groundwater samples of rainy period: TDS-EC; $\mathrm{NH}_{3}-\mathrm{EC} ; \mathrm{B}^{-\mathrm{NO}_{3}}$; Cl-EC and TDS; Mg-T.Hard; Na-EC, TDS, $\mathrm{NH}_{3}$ and $\mathrm{Cl}$; Ni-Co; $\mathrm{V}-\mathrm{EC}$, TDS, $\mathrm{NH}_{3}, \mathrm{Cl}$ and $\mathrm{Na}$ element pairs have very high positive correlation (Table 9). But $\mathrm{Ca}-\mathrm{NO}_{3} ; \mathrm{Cl}-\mathrm{T}$.Alkalinity and B; $\mathrm{Co}-\mathrm{T}$, alkalinity; $\mathrm{Mg}-\mathrm{Ca} ; \mathrm{Na}-\mathrm{B} ; \mathrm{Sr}_{-} \mathrm{NO}_{3}$ and B; V-T.Alkalinity element pairs show a high negative correlation.

In the analyses of old periods, uniform distribution maps belonging element pairs of EC- $\mathrm{NH}_{3}$ and $\mathrm{Na}-\mathrm{V}$ having very high positive correlation exhibit similar appearances (Figure 6) (Table 9). Nevertheless, each element of $\mathrm{Ca}-\mathrm{Mg}$ and $\mathrm{Cr}$ - $\mathrm{Li}$ element pairs in groundwater concentration having moderate negative correlation demonstrates different distributions (Figure 6 and 7). When Figure 6, 7 and 8 were examined, it was determined that element pairs such as $\mathrm{Ca}-\mathrm{Li}, \mathrm{Fe}-\mathrm{Na}$ and $\mathrm{Ni}-\mathrm{V}$ had different concentration 
distributions with each other. No correlation with one another was found in correlation analyses of them (Table 9).

Table 9. Correlation coefficients between the element pairs of the water samples of rainy period

\begin{tabular}{|c|c|c|c|c|c|c|c|c|c|c|c|c|c|c|c|c|c|c|c|c|c|c|}
\hline & $\mathrm{pH}$ & EC & TDS & T Alk. & T Hard. & Turb. & $\mathrm{NH3}$ & $\mathrm{NO3}$ & $\mathrm{SO} 4$ & $B$ & $\mathrm{Ca}$ & $\mathrm{Cl}$ & Co & $\mathrm{Cr}$ & $\mathrm{Fe}$ & $K$ & $L i$ & $\mathrm{Mg} / \mathrm{N}$ & $\mathrm{Na}$ & $\mathrm{Ni}$ & $\mathrm{Sr}$ & $\mathrm{V}$ \\
\hline $\mathrm{pH}$ & 1,00 & & & & & & & & & & & & & & & & & & & & & \\
\hline EC & 0,48 & 1,00 & & & & & & & & & & & \multicolumn{10}{|c|}{ Very high positive correlation ( 0.85 to 1.00 ) } \\
\hline TDS & 0,40 & 0,98 & 1,00 & & & & & & & & & & \\
\hline T Alk. & $-0,13$ & $-0,54$ & $-0,50$ & 1,00 & & & & & & & & & \multicolumn{10}{|c|}{ Moderate positive correlation ( 0.45 to 0.60$)$} \\
\hline T Hard. & 0,69 & 0,73 & 0,72 & $-0,30$ & 1,00 & & & & & & & & \multicolumn{10}{|c|}{ Low positive correlation ( 0.30 to 0.45 ) } \\
\hline Turb. & 0,69 & 0,28 & 0,23 & $-0,13$ & 0,64 & 1,00 & & & & & & & \multicolumn{10}{|c|}{ No correlation $(-0.30$ to 0.30$)$} \\
\hline $\mathrm{NH3}$ & 0,42 & 0,88 & 0,81 & $-0,43$ & 0,59 & 0,28 & 1,00 & & & & & & \multicolumn{10}{|c|}{ Low negative correlation $(-0.45$ to -0.30$)$} \\
\hline NO3 & $-0,44$ & $-0,49$ & $-0,50$ & 0,30 & $-0,13$ & 0,05 & $-0,20$ & 1,00 & & & & & \multicolumn{10}{|c|}{ Moderate negative correlation $(-0.60$ to -0.45$)$} \\
\hline SO4 & 0,52 & 0,60 & 0,61 & 0,18 & 0,55 & 0,09 & 0,39 & $-0,57$ & 1,00 & & & & \multicolumn{10}{|c|}{ High negative correlation $(-1.00$ to -0.60$)$} \\
\hline$B$ & $-0,58$ & $-0,58$ & $-0,54$ & 0,45 & $-0,26$ & $-0,26$ & $-0,34$ & 0,91 & $-0,50$ & 1,00 & & & & & & & & & & & & \\
\hline $\mathrm{Ca}$ & $-0,15$ & $-0,13$ & $-0,06$ & 0,03 & $-0,48$ & $-0,41$ & $-0,39$ & $-0,69$ & 0,11 & $-0,46$ & 1,00 & & & & & & & & & & & \\
\hline $\mathrm{Cl}$ & 0,40 & 0,96 & 0,95 & $-0,73$ & 0,64 & 0,28 & 0,82 & $-0,51$ & 0,41 & $-0,62$ & $-0,06$ & 1,00 & & & & & & & & & & \\
\hline Co & $-0,20$ & 0,07 & 0,12 & $-0,64$ & $-0,15$ & $-0,33$ & $-0,24$ & $-0,45$ & $-0,17$ & $-0,34$ & 0,58 & 0,25 & 1,00 & & & & & & & & & \\
\hline $\mathrm{Cr}$ & $-0,40$ & 0,21 & 0,32 & $-0,14$ & 0,09 & $-0,44$ & $-0,16$ & $-0,23$ & 0,36 & $-0,06 \mid$ & 0,27 & 0,20 & 0,50 & 1,00 & & & & & & & & \\
\hline $\mathrm{Fe}$ & 0,31 & $-0,05$ & $-0,01$ & $-0,42$ & 0,20 & 0,27 & $-0,39$ & $-0,39$ & $-0,06$ & $-0,40 \mid$ & 0,37 & 0,10 & 0,70 & 0,21 & 1,00 & & & & & & & \\
\hline K & $\mid-0,37$ & $-0,13$ & $-0,13$ & 0,29 & $-0,45$ & $-0,39$ & $-0,15$ & $-0,17$ & 0,24 & $|-0,12|$ & 0,41 & $-0,19$ & 0,09 & 0,30 & $-0,27$ & 1,00 & & & & & & \\
\hline $\mathrm{Li}$ & 0,37 & 0,53 & 0,45 & $-0,19$ & 0,25 & 0,48 & 0,72 & $-0,16$ & 0,17 & $-0,39$ & $-0,14$ & 0,51 & $-0,32$ & $-0,48$ & $-0,36$ & 0,21 & 1,00 & & & & & \\
\hline $\mathrm{Mg}$ & 0,52 & 0,79 & 0,76 & $-0,32$ & 0,91 & 0,52 & 0,81 & 0,05 & 0,44 & $-0,12$ & $-0,66$ & 0,70 & $-0,31$ & $-0,01$ & $-0,16$ & $-0,40$ & 0,42 & 1,00 & & & & \\
\hline $\mathrm{Na}$ & 0,48 & 0,99 & 0,95 & $-0,52$ & 0,66 & 0,27 & 0,87 & $-0,55$ & 0,64 & $-0,66$ & $-0,08$ & 0,94 & 0,06 & 0,19 & $-0,07$ & 0,00 & 0,59 & 0,73 & 1,00 & & & \\
\hline $\mathrm{Ni}$ & $-0,42$ & $-0,07$ & 0,03 & $-0,28$ & $-0,35$ & $-0,50$ & $-0,43$ & $-0,48$ & $-0,01$ & $-0,29$ & 0,78 & 0,06 & 0,86 & 0,70 & 0,51 & 0,40 & $-0,39$ & $-0,52$ & $-0,04$ & 1,00 & & \\
\hline $\mathrm{Sr}$ & 0,04 & 0,58 & 0,62 & $-0,31$ & 0,20 & 0,06 & 0,27 & $-0,62$ & 0,51 & $-0,68$ & 0,35 & 0,60 & 0,24 & 0,56 & 0,10 & \begin{tabular}{|l|}
0,33 \\
\end{tabular} & 0,25 & 0,15 & 0,64 & 0,45 & 1,00 & \\
\hline V & 0,33 & 0,97 & 0,95 & $-0,61$ & 0,61 & 0,13 & 0,90 & $-0,43$ & \begin{tabular}{|l|}
0,49 \\
\end{tabular} & $-0,50$ & $-0,15$ & 0,96 & 0,13 & 0,22 & $\mid-0,14$ & $-0,08$ & 0,52 & 0,75 & 0,96 & $-0,03$ & 0,53 & 1,00 \\
\hline
\end{tabular}

Three significant groups appear in the cluster analysis of the groundwater samples of dry period (Figure 11). The first group is named as "Main Component Group" and consists of (EC-TDS-Sr-Mg-Na-NH ${ }_{3}-\mathrm{K}-\mathrm{Turb}$.T.Hard.-Li)-SO $\mathrm{S}_{4}$. The second group is "Metal Group" and it consists of ( $\left.\mathrm{Cr}-\mathrm{Ni}\right)-\mathrm{Fe}$. The other group is "Cl Group" and it consists of B-Cl.

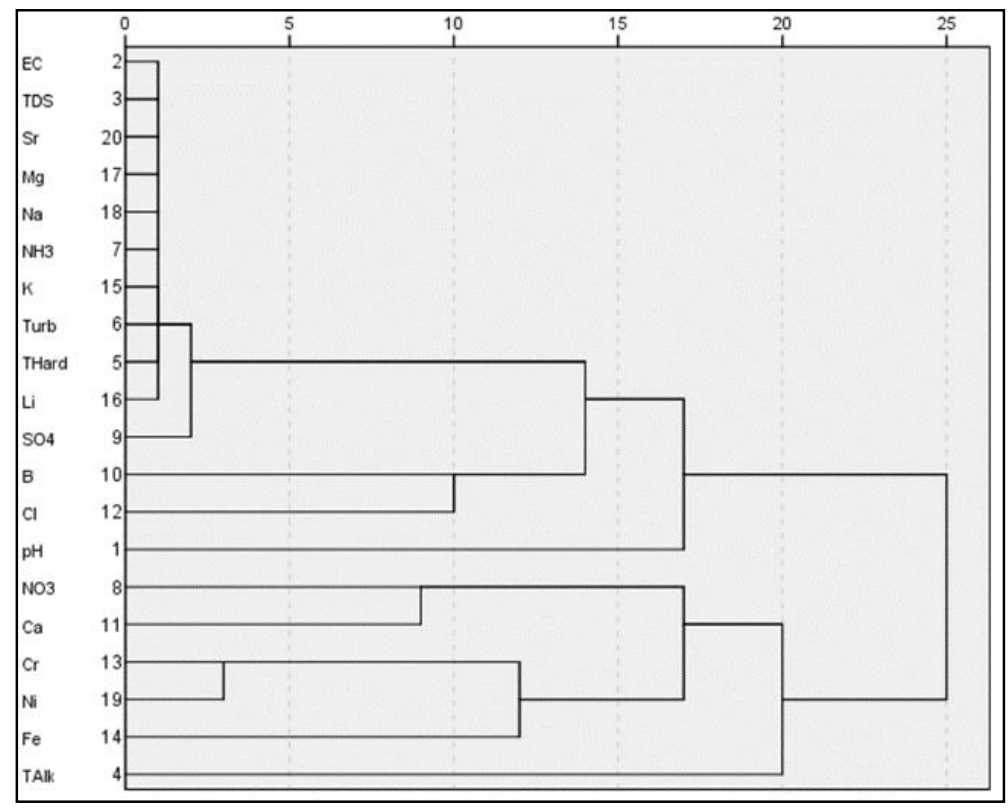

Figure 11. Cluster analysis graphic of the water samples of dry period

Three significant group appears on the cluster analysis of the groundwater samples of rainy period (Figure 12). The first group is named as "Main Component Group" and consists of (EC-TDS-Na-V-Cl)- $\mathrm{NH}_{3}-((\mathrm{Mg}-$ T.Hard.)-(pH-Turb))-Sr-SO ${ }_{4}$. The Second significant group is named as "Metal Group" and consists of ((((CO$\mathrm{Ni})-\mathrm{Ca})-\mathrm{Cr})-\mathrm{Fe})-\mathrm{K}$. The third group is named as "B Group" and consists of (B-NO 


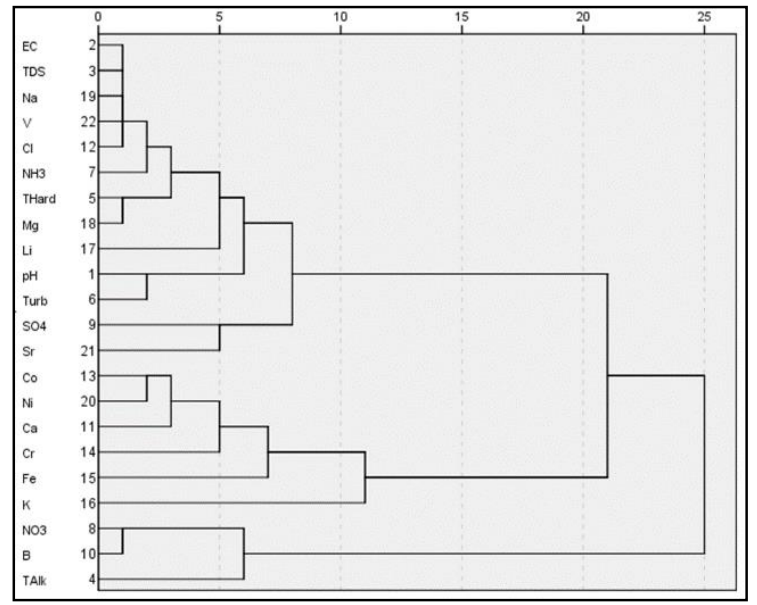

Figure 12. Cluster analysis graphic of the water samples of rainy period

\section{Conclusions and Recommendations}

The following results were obtained in the study on which the effect of the third OIZ, in which $90 \%$ of the factory consists of chemistry, glass, metal and machine production, to the groundwater pollution is based.

According to the concentration distribution maps belonging to both periods, increased levels of $\mathrm{EC}, \mathrm{Cl}, \mathrm{Li}$, $\mathrm{Mg}, \mathrm{Mn}, \mathrm{Na}, \mathrm{V}, \mathrm{SO}_{4}, \mathrm{Sr}, \mathrm{Ca}$, and $\mathrm{NH}_{3}$ appeared near the east or the north-eastern parts of the study area. $\mathrm{Zn}$ appeared to have intensified in the central part, while other elements have increased in other directions. Results also showed that the groundwater has been affected by industrial activities in the OIZ, since $\mathrm{Cr}, \mathrm{Mg}, \mathrm{Fe}$, and $\mathrm{Ni}$ concentrations were found to be high in all samples, while $\mathrm{Co}, \mathrm{Fe}$, $\mathrm{Li}$, and $\mathrm{Sr}$ concentrations were found in changing amounts. This contamination is mainly due to storage areas and waste belonging to the chemical and metal industries and the factories that produces electrical machines and equipment.

Water samples is usually in the class "mixed compound waters, none of the ions of which exceeds 50\%" in both periods according to the Piper diagram when evaluated in terms of water quality. Water samples are mainly classified as "well-usable for irrigation purposes" according to the Wilcox diagram. However, 2 and 10 numbered samples are classified "suspicious-not appropriate", 1 and 11 numbered samples are classified as "not appropriate" during the rainy period.

It was determined that $\mathrm{NO}_{3}, \mathrm{SO}_{4}, \mathrm{Ca}, \mathrm{Cl}, \mathrm{Na}, \mathrm{Cr}, \mathrm{Fe}, \mathrm{Mg}, \mathrm{Mn}, \mathrm{Ni}$ and $\mathrm{Zn}$ levels exceeded the $\mathrm{MCL}$ in samples according to WHO, EPA and EC drinking water standards. Furthermore, it was established that the water samples of rainy period had higher concentrations than that of dry one. The washing of storage and production areas of factories located in the OIZ in rainy period causes the infiltration of contaminants from the ground to underground. Also due to leakage from the sewage system, an increase in concentration of the elements at the samples taken from groundwater in rainy period when compared with dry period is observed.

In the analyses performed, maximum conductivity values displayed alterations between 4380 (wet period) and 6900 (dry period) $\mu$ mhos $\mathrm{cm}^{-1}$. The fact that conductivity values were so high and that, in nearly all samples, $\mathrm{Ca}$ and $\mathrm{SO}_{4}$ concentrations exceeded $\mathrm{MCL}$ values indicates that such values are caused by salt and gypsum levels in the aquifer. Parallel to this, $\mathrm{Ca}, \mathrm{Cl}, \mathrm{Na}$, and $\mathrm{SO}_{4}$ concentrations were spread such a large area that they suit the boundary of the Aslımyayla formation, which constitutes a natural contamination source for the study area due to its salt and gypsum layers. That $\mathrm{NO}_{3}$ exceeds $\mathrm{MCL}$ in some samples is mainly due to fertilizers used in agricultural activities in the area around the $\mathrm{OIZ}$, reach to irrigation water and groundwater.

In correlation analyses of groundwater samples, it was determined that element pairs in dry and wet seasons had a correlation changing from positive to negative. Of these results, it was found out that very 
similar distributions in uniform concentration maps of groundwater of element pairs with high positive correlation were existed. It was determined that there was a very close relationship between statistical results changing from moderate correlation to high correlation and concentration distribution maps.

In cluster analyses of groundwater samples, it is seen that the number of alignment has increased according to dry season graphic in wet season graphic and that the differentiation has become evident. In wet season, there has been witnessed that there has been a decrease in the number of element in "Main Component Group", while there has been an increase in "Metal Group". This crucial differentiation in wet season shows that climatic conditions and changes in chemistry of ground water depending on precipitation increase are very influential.

In cluster analyses of dry season, it has been determined that the elements under "Main Component Group" have encompassed the elements having high concentrations in the analyses of this period. Cluster analysis results prove that water samples are in close relations with the analyses.

According to data from analyses and on site measurements of groundwater samples obtained from wells within the study area, the groundwater of the OIZ is alarmingly contaminated due to rapid industrialization. However, the results of this investigation also suggest that the area's geological properties pose another threat to the area's groundwater. In addition to all these, it is determined that the underground water in the area has a risk in terms of public health.

According to results obtained by this study, the following suggestions should be considered:

Firstly, to prevent contamination stemming from industrial activity, it is necessary that solid and liquid waste be disposed so that they will not infiltrate the groundwater. Secondly, regular groundwater quality monitoring network stations should be established throughout suitable observation wells. Thirdly, there should be sufficient distance between sewage and drinking water supply lines to avoid crosscontamination. Finally, by means of this study, it is well comprehended that it is essential aquifers where the need for drinking water and utilization water can be met should be chosen from the areas which do not pose a threat in terms of public health.

The untreated effluence emerging from industries in Konya's third OIZ must be monitored in order to maintain the standards prescribed by the pollution control board for various industries in the region. At the same time, to prevent contamination that can stem from lithology, it is necessary that wells drilled in the area be planned so that they can be isolated from salt and gypsum deposits.

\section{Acknowledgments}

This investigation was supported by Selcuk University Scientific Research Projects Support Program (SU-BAP Project No: 10201063$)$.

\section{References}

Afzal M., Shabir G., Iqbal S., Mustafa T., Khan Q.M. and Khalid Z.M. (2014), Assessment of Heavy Metal Contamination in Soil and Groundwater at Leather Industrial Area of Kasur, Pakistan, CLEAN-Soil, Air, Water, 42(8), 1133-1139.

Arundas A. (2010), Monitoring Contaminants In Konya Organized Industrial Zone Sewerage System, M.Sc. Thesis, Department of Environmental Engineering, University of Selcuk (in Turkish).

APHA (1992), Standard Methods for The Examination of Water and Wastewater, American Public Health Association, Washington DC.

Azizullah A., Khattak M.N.K., Richter P. and Häder D.P. (2011), Water Pollution in Pakistan and Its Impact On Public Health-A Review, Environment International, 37, 479-497.

Dasaram B., Satyanarayanan M., Krishna A.K. and Sudarshan V. (2011), Trace Elements Geochemistry of Groundwater: A Case Study from Patancheru Industrial Area, Andhra Pradesh, India, J. of Applied Geochemistry, 13(2), 220-228.

EC (2007), European Communities (Drinking Water) Regulations, ISBN 1-4064-1295-3.

EPA (2009), National Primary Drinking Water Regulations, EPA 816-F-09-004. 
Eren Y. (2001), Neo-tectonic Features and Earthquake of Konya and Surroundings, 1 st Symp of Konya According to Geosciences, Turkey, 17-19 (in Turkish).

Gowd S.S. and Govil P.K. (2008), Distribution of Heavy Metals in Surface Water of Ranipet Industrial Area in Tamil Nadu, India, Environ Monit Assess, 136, 197-207.

Hakyemez H.Y., Elibol E., Umut M., Bakirhan B., Kara I., Dagistan R., Metin T. and Erdogan N. (1992), Geology of Konya-Çumra-Akören, General Directorate of Mineral Research and Exploration (MTA), Rep. No. 9449, Turkey (in Turkish).

Krishna A.K., Satyanarayanan M. and Govil P.K. (2009), Assessment of Heavy Metal Pollution in Water Using Multivariate Statistical Techniques in an Industrial Area: A Case Study From Patancheru, Medak District, Andhra Pradesh, India, J. of Hazardous Materials, 167, 366-373.

Krishna A.K. and Mohan K.R. (2014), Risk Assessment of Heavy Metals and Their Source Distribution in Waters of a Contaminated Industrial Site, Environmental Science and Pollution Research, 21(5), 3653-3669.

Nalbantcilar M.T. (2002), Groundwater Quality and Contamination of Konya Settlement Area, Ph.D. Thesis, Department of Geological Engineering, University of Selcuk (in Turkish).

Nalbantcilar M.T. and Guzel A. (2006), Trace Element Pollution of Drinking Water Supply of Konya, Turkey, J. Geological Society of India, 68, 1087-1092.

Nalbantcilar M.T. (2008), Useful Vulnerability Mapping Methods for Getting Groundwater: DRASTIC, $8^{\text {th }}$ Int. Scientific Conference Modern Management of Mine Producing, Geology and Environmental Protection (SGEM 2008), Bulgaria, Vol. II, 29-31.

Nalbantcilar M.T. and Ozdemir A. (2009), Environmental Problem as Result From Chemistry of Solid Waste Area Leachate of Konya (Turkey), Taibah International Chemistry Conference, Saudia Arabia, 175.

Nalbantcilar M.T., Guzel A. and Durduran S.S. (2009), Assessing of Groundwater Vulnerability Contamination Potential of Konya, Turkey, Using Hydrogeological Specifications and GIS, Asian Journal of Chemistry, 21(4), 2925-2934.

Nalbantcilar M.T. (2011), Assessment of The Vulnerability Potential for an Unconfined Aquifer in Konya Province, Turkey, In Integrated Waste Management (ISBN 978-953-307-447-4), Croatia, Vol. II, 431-438.

Nalbantcilar M.T. and Pinarkara D. (2011), Groundwater Contamination In 3. Organized Industrial Area (Konya), Selcuk University Scientific Research Project, Project No: 10201063, Turkey (in Turkish).

Nas B. (1998), Determination of Pollution Loads for Konya $2^{\text {nd }}$ and $3^{\text {rd }}$ Organized Industrial District, M.Sc. Thesis, Department of Environmental Engineering, University of Selcuk (in Turkish).

Ozdemir A. and Aydin M.E. (1998), Chemical Properties of Groundwater in the Konya Residential Area, J. Eng. Arch. Fac. Selcuk University, 13(1), 37-47 (in Turkish).

Pinarkara D. (2011), Groundwater Contamination In $3^{\text {rd }}$ Organized Industrial Area (Konya), M.Sc. Thesis, Department of Geological Engineering, University of Selcuk (in Turkish).

Piper A.M. (1944), A Graphic Procedure in Geochemical Interpretation of Water Analyses, American Geophysical Union Transactions, 25, 914-923.

Shankar B.S., Balasubramanya N. and Maruthesha Reddy M.T. (2008), Impact of Industrialization on Groundwater Quality-A Case Study of Peenya Industrial Area, Bangalore, India, Environ Monit Assess, 142, 263-268.

Sponza D. and Karaoglu N. (2002), Environmental Geochemistry and Pollution Studies of Aliağa Metal Industry District, Environment International, 27, 541-553.

Ullah R., Malik R.N. and Qadir A. (2009), Assessment of Groundwater Contamination in an Industrial City, Sialkot, Pakistan, African Journal of Environmental Science and Technology, 3(12), 429-446.

WHO (2011), Guidelines For Drinking-water Quality; 4th ed., ISBN 9789241548151, Annex 3-Chemical Summary Tables, 472-474.

Wilcox L.V. (1955) Classification and Use of Irrigation Waters, US Dept. Agric. Circ. 969, 19 p., Washington DC.

Yildiz A., Karaca M., Biceroglu S., Nalbantcilar M.T., Coskun U., Arik F., Aliyev F., Yiginer O. and Turkoglu C. (2008), Effect of Chronic Arsenic Exposure from Drinking Waters on the QT Interval and Transmural Dispersion of Repolarization, The Journal of International Medical Research, 36, 471-478. 